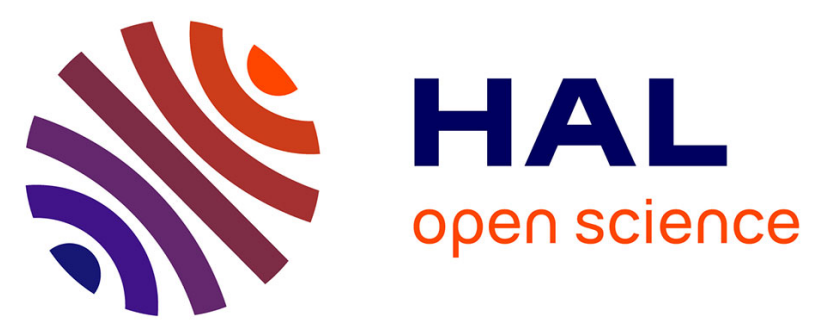

\title{
Long-term assessment of geochemical reactivity of CO2 storage in highly saline aquifers: Application to Ketzin, In Salah and Snøhvit storage sites
}

\author{
Joachim Tremosa, Christelle Castillo, Chan Quang Vong, Christophe
}

Kervévan, Arnault Lassin, Pascal Audigane

\section{To cite this version:}

Joachim Tremosa, Christelle Castillo, Chan Quang Vong, Christophe Kervévan, Arnault Lassin, et al.. Long-term assessment of geochemical reactivity of $\mathrm{CO} 2$ storage in highly saline aquifers: Application to Ketzin, In Salah and Snøhvit storage sites. International Journal of Greenhouse Gas Control, 2014, 20, pp.2-26. 10.1016/j.ijggc.2013.10.022 . hal-00921634

\section{HAL Id: hal-00921634 \\ https: / hal-brgm.archives-ouvertes.fr/hal-00921634}

Submitted on 20 Dec 2013

HAL is a multi-disciplinary open access archive for the deposit and dissemination of scientific research documents, whether they are published or not. The documents may come from teaching and research institutions in France or abroad, or from public or private research centers.
L'archive ouverte pluridisciplinaire HAL, est destinée au dépôt et à la diffusion de documents scientifiques de niveau recherche, publiés ou non, émanant des établissements d'enseignement et de recherche français ou étrangers, des laboratoires publics ou privés. 


\title{
Long-term Assessment of Geochemical Reactivity of $\mathrm{CO}_{2}$ Storage in Highly Saline Aquifers: Application to Ketzin, In Salah and Snøhvit storage sites
}

Joachim Trémosa, Christelle Castillo, Chan Quang Vong, Christophe Kervévan, Arnault Lassin and Pascal Audigane

BRGM, Bureau de Recherches Géologiques et Minières

3 Av. Claude Guillemin, 45060 Orléans, France

Corresponding author: j.tremosa@brgm.fr

\begin{abstract}
Saline aquifers are choice targets for geological storage of $\mathrm{CO}_{2}$ because of their storage potential and because these formations are not suitable for other uses. Geochemical modeling is an interesting tool to assess the geochemical behavior of $\mathrm{CO}_{2}$ in the saline aquifer, including its dissolution in the brine and its interactions with minerals. Two key parameters which determine the confidence one can have in the results of geochemical modeling are tested in this paper: i) the establishment of the conceptual model, including the selection of the primary and secondary minerals expected to react; and ii) the activity model and the associated thermodynamic databases to calculate the interaction energies within the saline solution. In this study, we performed an analysis of a large set of $\mathrm{CO}_{2}$ storage natural analogues, which makes it possible to identify the minerals that are likely to precipitate and dissolve during $\mathrm{CO}_{2}$ - brine - rock interactions. Interestingly, this analysis indicates a strong dependence of dawsonite precipitation on the initial sandstone mineralogy. Dawsonite can precipitate in lithic and feldspar rich sandstones but was not observed in quartz rich sandstones. These observations on mineral reactivity are used to establish reactivity conceptual models for three $\mathrm{CO}_{2}$ storage case-studies in saline sandstone aquifers (Ketzin, In Salah and Snøhvit) and a methodology is proposed to evaluate the long-term geochemical reactivity of these saline aquifers as a result of $\mathrm{CO}_{2}$ injection. Noticeable differences are obtained between the case-studies as a function of the initial mineralogy and chemical conditions in the sandstones, which highlight that $\mathrm{CO}_{2}$ mineral trapping can take place in a given storage site but can be almost absent in other storage sites. Regarding the activity model and the database, the Pitzer interaction model is rarely used for simulating $\mathrm{CO}_{2}$ geochemical behavior in saline aquifers despite the fact that more conventionally
\end{abstract}


used activity models are not valid for such salinities. A comparison between calculated mineral solubility evolution with salinity versus experimental data is performed here using both B-dot and Pitzer activity models as well as six different databases. This comparison exercise shows that chemical interactions within saline solutions can only be reproduced using the Pitzer model, even though Pitzer databases are still incomplete or are not coherent for a wide range of chemical species and temperatures. The geochemical simulations of $\mathrm{CO}_{2}$ injection in Ketzin, In Salah and Snøhvit saline aquifers give divergent results using different activity models and databases. A high uncertainty on the simulation results is then linked to the database choice and this study clearly stresses the need for a Pitzer database that can be confidently used in all physical/chemical conditions found in deep sedimentary aquifers.

\section{Introduction}

Carbon capture and storage (CCS) is considered as a promising option to limit the effects of anthropogenic greenhouse gas emissions on climate change (IPCC, 2007). Deep saline aquifers are interesting targets for geological storage of carbon dioxide $\left(\mathrm{CO}_{2}\right)$ because of their storage potential and because these formations are not suitable for other uses. Indeed, waters from deep saline aquifers in sedimentary basins have salinities ranging from 5 to $>350 \mathrm{~g} \mathrm{~L}^{-1}$ and contain dissolved toxic and radioactive metals which limit their use as a resource, in particular for potable use (Kharaka and Hanor, 2003). Before implementing CCS technology on a large scale, the viability of this technology must be evaluated and uncertainties must be removed regarding injectivity, containment and longterm safety. Within this purpose of assessing the viability of $\mathrm{CO}_{2}$ storage, it is essential to predict the geochemical behavior of the $\mathrm{CO}_{2}$ in the reservoir and in the underground media as well as the chemical and mineralogical changes linked to $\mathrm{CO}_{2}$ injection. Assessing the geochemical evolution is mainly required for predicting near-well interactions which can alter injectivity, $\mathrm{CO}_{2}$ trapping in the reservoir, interactions with the caprock and leakage pathways and chemical impacts in overlying aquifers (Gaus, 2010).

Different complementary methods can be undertaken to assess the behavior of the $\mathrm{CO}_{2}$ stored in saline sandstone aquifers and its interactions with water and the minerals of the host formation $\mathrm{CO}_{2}$ fluid-rock in a storage site (Czernichoswki-Lauriol et al., 2006; Gaus, 2010). The first method is the characterization of natural $\mathrm{CO}_{2}$ storage sites, which makes it possible to consider geological timescales at the reservoir and basin scales. The second method consists in laboratory experiments, which provide direct observations of $\mathrm{CO}_{2}$-fluid-rock interactions, but at the experiment duration and spatial scales. Field and demonstration tests are also a valuable way to obtain information on the interactions occurring during $\mathrm{CO}_{2}$ injection. However, only changes in gas and water compositions 
are generally monitored during these tests and not changes on the rock. The last method is numerical geochemical and reactive transport modeling, which can be used to interpret and simulate natural analogues, laboratory experiments and field tests or to predict the behavior of a $\mathrm{CO}_{2}$ geological storage, including over large time and spatial scales. In order to make accurate simulations and predictions, modeling requires a good description of the processes taking place and a precise characterization of the parameters involved in the calculations.

In geochemical modeling, the quality of the calculations is determined by the constraint of some key parameters and processes: the thermo-physical properties of $\mathrm{CO}_{2}$, the interactions within the brine, the selection of the reacting mineral phases and their solubility properties and the kinetic laws and parameters (Marini, 2006; Gaus et al., 2008). Constraining these parameters is a challenging but essential task to understand and accurately simulate the geochemical evolution of a $\mathrm{CO}_{2}$ storage. This work is focused on the selection of the minerals to consider in a model and on the influence of the different options offered to a modeler for describing the interaction processes within the solution.

Many modeling studies on the geochemical evolution of $\mathrm{CO}_{2}$ storages including mineral changes have been carried out over recent years (Xu et al., 2003, 2010; Knauss et al., 2005; Lagneau et al., 2005; Zerai et al., 2006; Audigane et al., 2007, 2009). However, the selection of the minerals involved in the interaction processes does not always rest on a solid conceptual model specific to the studied storage site. Indeed, it is essential to first interpret in terms of reactivity the mineral and pore solution initial states and, then, based on natural system observations and on laboratory interaction experiments, to establish what reactions are expected when $\mathrm{CO}_{2}$ is introduced into this particular water - rock system. All primary minerals are sometimes considered in the simulation (Xu et al., 2003; Zhang et al., 2009), without any consideration of the minerals really expected to react, and the behavior of the system is controlled by the thermodynamics and the kinetics of the reaction, in spite of their uncertainties. This kind of simulation leads to a complicated and certainly erroneous behavior where some primary minerals replace in several years or hundreds of years other primary minerals because they are thermodynamically more stable, although these minerals can coexist in natural systems over millions of years. Furthermore, the selection of the secondary minerals resulting from $\mathrm{CO}_{2}$ injection into sandstone is still under debate, in particular for dawsonite. Under storage conditions, this $\mathrm{Na}-\mathrm{Al}$ carbonate is thermodynamically favored to precipitate but is not often observed in $\mathrm{CO}_{2}$ natural storage analogues and never in laboratory experiments at low $\mathrm{pH}$ and temperatures relevant for $\mathrm{CO}_{2}$ storage. The purpose is then to be able to establish a solid conceptual model clearly pointing out the minerals likely to react in a given sandstone, in coherence with the overall observations from natural analogues and experiments, as a function of the mineralogical and 
chemical properties of the studied formation (Gaus, 2010; Dethlefsen et al., 2011; Hellevang et al., 2011). Such a good constraint on the conceptual model appears all the more important in that it has been demonstrated that mineral trapping is highly influenced by the selection of the initial and secondary minerals (Kihm et al., 2012).

When performing geochemical simulations in deep saline aquifers, it should be recalled that the high pressure, temperature and salinity characterizing these aquifers confer to the system a different chemical behavior than in surface conditions. Conventional activity models of Debye-Hückel type are frequently used in simulations of $\mathrm{CO}_{2}$ storage in deep saline aquifers, even though these models are only valid for dilute solutions. Likewise, thermodynamic databases are also used out of their temperature validity range or for chemical species without interaction coefficients in Pitzer databases. On this topic, the purpose of this paper is to evaluate the uncertainty of the activity model and the thermodynamic database used on the simulation results. This paper investigates the conditions to assess the geochemical behavior of $\mathrm{CO}_{2}$ storage in deep saline aquifers aiming at improving the establishment of the conceptual model and at evaluating the effect of the activity model and thermodynamic database selection on the simulation results. These subjects are illustrated and discussed on the basis of three case studies: Ketzin, In Salah and Snøhvit $\mathrm{CO}_{2}$ storage sites.

\section{Geochemical modeling approach for $\mathrm{CO}_{2}$ storage in saline aquifers}

\subsection{Conceptual model of long-term $\mathrm{CO}_{2}$ evolution in saline sandstone aquifers: insights provided by natural analogues}

In a $\mathrm{CO}_{2}$ geological storage, $\mathrm{CO}_{2}$ is injected into the host formation in a supercritical state and will distribute according to four trapping mechanisms, namely structural, residual, solubility and mineral trapping, respectively to the increase of storage safety (Benson and Cole, 2008). The distribution of $\mathrm{CO}_{2}$ in these four traps will evolve over time, distance from the injection point and physical conditions $(P, T$, salinity) in the host formation. From a geochemical perspective and over long time spans, perturbations linked to $\mathrm{CO}_{2}$ will mainly concern the dissolved $\mathrm{CO}_{2}$ and the interaction with the rock.

The dissolution of $\mathrm{CO}_{2}$ in brines leads to an acidification and an increase in bicarbonate content, which have important consequences regarding the evolution of the geochemical system in the saline 
sandstone aquifer. Information on the resulting interactions is given by laboratory experiments and by the study of natural $\mathrm{CO}_{2}$ geological disposal analogues. During laboratory interaction experiments between $\mathrm{CO}_{2}$ saturated brines and sandstones or rock-constituting minerals (e.g., Kaszuba et al., 2003, 2005; Hangx and Spiers, 2009; Ketzer et al., 2009; Luquot et al., 2012), only fast reactions can be observed but system conditions are well controlled, allowing a precise characterization of the observed interaction processes. Natural analogues make it possible to observe the results of $\mathrm{CO}_{2}-$ water - rock interactions over geological periods, mainly regarding the dissolution and precipitation of minerals obeying slow reaction kinetics. However, in natural analogues uncertainties remain regarding the fluid and gas compositions during the interaction with $\mathrm{CO}_{2}$, the initial mineralogy, the temperature during interaction and the interaction duration. A compilation of natural analogues of $\mathrm{CO}_{2}$ storage in saline aquifers is presented in Table 1. It emphasizes the changes in mineralogy that occurred during $\mathrm{CO}_{2}$ intrusion in deep saline sandstone aquifers. It is necessary to consider both fast and slow $\mathrm{CO}_{2}$ - water - rock reactions given by laboratory experiments and natural analogues to establish an interaction model. These insights make it possible to select the minerals expected to react or to precipitate during the interaction with $\mathrm{CO}_{2}$ saturated brines, calibrate the model and compare the simulation results with data.

During the interaction of $\mathrm{CO}_{2}$ saturated brines and sandstones calcite, dolomite and sulfate minerals dissolve rapidly and the the solutions are close to equilibrium with these phases. Such fast reactions are observed during laboratory experiments and evidenced in natural analogues. Aluminosilicate primary sandstone minerals, such as feldspars, clay minerals, micas, chlorites or zeolites, also tend to dissolve because of the brine acidity. However these minerals have slow rates of dissolution and can persist over geological periods in thermodynamically unstable conditions. Natural analogues (Table 1) present dissolution footprints on primary aluminosilicate minerals but these minerals are still present even after several Ma of interaction. The dissolution of primary rock minerals induces a supply of cations in the brine, such as $\mathrm{Ca}, \mathrm{Mg}, \mathrm{Na}, \mathrm{Al}, \mathrm{Fe}$ and $\mathrm{Si}$, which are available for precipitation of secondary minerals. Chalcedony or quartz are expected to precipitate relatively rapidly, since their precipitation is observed during $\mathrm{CO}_{2}$ - sandstone interaction experiments accelerated using higher temperature and pressure than in the aquifers (Kaszuba et al., 2005) or even during experiments at in situ temperature and pressure (Luquot et al., 2012). With a few exceptions, quartz precipitation linked to $\mathrm{CO}_{2}$ intrusion is observed in almost all natural analogues (Table 1). These exceptions are probably due to the difficulty of dating all quartz cementations in the rock in relation to their diagenesis event. Kaolinite is expected to precipitate as a result of primary aluminosilicate mineral 
dissolution. Kaolinite precipitation is slow and is commonly observed in natural analogues but rarely during laboratory experiments (Ketzer et al., 2009; Luquot et al., 2012).

$\mathrm{CO}_{2}$ mineral trapping occurs because of precipitation of carbonate minerals, in relation to the available dissolved cations in the brine. Commonly observed carbonate phases are calcite, dolomite, ankerite, siderite and dawsonite (Table 1). Precipitation of $\mathrm{Ca}, \mathrm{Mg}$ and Fe carbonates are observed in all $\mathrm{CO}_{2}$ storage analogues. Precipitation of dawsonite $\left(\mathrm{NaAlCO}_{3}(\mathrm{OH})_{2}\right)$ is not observed in all cases after interaction with $\mathrm{CO}_{2}$ rich brines. The introduction of dawsonite into geochemical simulations of $\mathrm{CO}_{2}$ storage in saline aquifers is controversial (Haszeldine et al., 2005; Hellevang et al., 2005, 2011; Kaszuba et al., 2011) since its precipitation is predicted by numerical simulations (Xu et al., 2003; Audigane et al., 2007) but dawsonite has rarely been observed in sedimentary basins (Smith and Milton, 1966; Baker et al., 1995). The thermodynamic properties of dawsonite were recently reevaluated (Benezeth et al., 2007) and confirm that this mineral can be thermodynamically stable under $\mathrm{CO}_{2}$ storage conditions (Cantucci et al., 2009). With regards to the thermodynamic database, it has also been pointed out that a consistent database for $\mathrm{Al}$ - phases and the Al system is required for a correct reproduction of dawsonite behavior (Kaszuba et al., 2011). Uncertainties regarding the kinetics of dawsonite precipitation and its nucleation have been suggested as a cause of the discrepancy between simulation predictions and field observations. The difference between rates measured during laboratory experiments and rates at the field scale is particularly uncertain to address (Zhu, 2005; Gannor et al., 2007). However, sensitivity analysis on the reaction rates and the nucleation rates (Hellevang et al., 2011) only indicate dawsonite precipitation is brought forward or postponed. After a long duration of interaction, dawsonite is predicted to precipitate. A dependence of the dawsonite precipitation rate on the aluminosilicate mineral dissolution rates has also been pointed out (Hellevang et al., 2010), because of a limited Al supply rate from aluminosilicates. It is difficult to estimate the time required for dawsonite to precipitate from the natural analogues. The only insight is given by the Bravo Dome analogue, where the absence of dawsonite can partly be explained by the too recent $\mathrm{CO}_{2}$ intrusion in the arkosic sandstone, which occurred 8,000 to 100,000 years ago (Baines and Worden, 2004). However, the mineralogical assemblage of Bravo Dome analogue also suggests the sandstone underwent open-system alteration, leaching out the sourceions for dawsonite. Further natural $\mathrm{CO}_{2}$ storage analogues have also been investigated in recent years and dawsonite precipitations were observed in various saline aquifers as a result of $\mathrm{CO}_{2}$ rich brine - sandstone interaction (Moore et al., 2005; Worden, 2006; Gao et al., 2009; Wilkinson et al., 2009; Liu et al., 2011; Zalba et al., 2011). Dawsonite precipitation related to $\mathrm{CO}_{2}$-rich fluid flooding has also been observed in carbonate veins in mudstone of the Cretaceous Izumi group (SW Japan), 
which can be considered as a natural analogue of $\mathrm{CO}_{2}$ storage caprock (Okuyama and Take, 2011). These studies on natural analogues indicate that dawsonite is more frequent than previously thought. It is also possible that dawsonite is missed in non-precise mineralogical and petrographical investigations since this mineral is characterized by a petrographical aspect similar to that of illites (Smith and Milton, 1966; Baines and Worden, 2004; Worden, 2006).

The influence of the initial composition of the sandstone can be considered to explain why dawsonite is sometimes observed in natural analogues and is sometimes absent. Dawsonite can precipitate from slightly acidic $\mathrm{Na}$ rich brines with high $\mathrm{CO}_{2}$ contents and a source of $\mathrm{Al}$ (Worden, 2006; Benezeth et al., 2007; Hellevang et al., 2011). Only a relatively moderate $\mathrm{CO}_{2}$ fugacity of some bars is required for the brine to be within the dawsonite stability zone (Worden, 2006). Studies on the reaction paths for dawsonite formation have shown that its precipitation follows the dissolution of an aluminosilicate mineral, such as a feldspar or a clay mineral (Johnson et al., 2001, 2004; Benezeth et al., 2007; Hellevang et al., 2011). Indeed, dawsonite is frequently observed to pseudomorphically replace feldspar crystals (Table 1). With regards to the temperature, dawsonite can form over a range from 25 to $120{ }^{\circ} \mathrm{C}$ (Table 1). An overall reaction is frequently proposed (Zerai et al., 2006; Audigane et al., 2007; Gaus, 2010) to represent the feldspar $\left(\mathrm{NaAlSi}_{2} \mathrm{O}_{8}\right)$ evolution to dawsonite $\left(\mathrm{NaAlCO}_{3}(\mathrm{OH})_{2}\right)$ and chalcedony $\left(\mathrm{SiO}_{2}\right)$ in $\mathrm{CO}_{2}$-rich brines. The reaction can be written as follows:

$$
\mathrm{NaAlSi}_{3} \mathrm{O}_{8}+\mathrm{CO}_{2}+\mathrm{H}_{2} \mathrm{O}=\mathrm{NaAlCO}_{3}(\mathrm{OH})_{2}+3 \mathrm{SiO}_{2}
$$

The compositions of the detrital phases of natural $\mathrm{CO}_{2}$ storage analogue sandstones are shown in a Folk's diagram (Figure 1) with a distinction between dawsonite bearing sandstones and sandstones without dawsonite. The mineralogical composition of the total rock (i.e., not only including the detrital phases) is given in Table 1 for each analogue. Note that the Folk's diagram (Figure 1) shows some uncertainty regarding the composition of several analogues: i) the available mineralogical compositions of the Bravo Dome and Vert le Grand analogues are not detailed; ii) for the Miller Field analogue, relatively different mineralogical compositions are given by the different authors (Marchand et al., 2001; Baines and Worden, 2004); and iii) the Aldebaran sandstones of the Bowen, Gunnedah and Sydney basins present heterogeneities so that their compositions vary from litharenite to quartzarenite (Baker et al., 1995) but there are no details as to whether dawsonite is encountered or not in all facies.

From the Folk's diagram, which reports fourteen natural $\mathrm{CO}_{2}$ geologic disposal analogues, a zonation of the sandstone compositions is highlighted regarding the occurrence or the absence of dawsonite. It appears that dawsonite bearing sandstones generally contain less quartz than sandstones without 
dawsonite. Figure 1 also indicates that reactive minerals, such as clay minerals or volcanic or metamorphic derived phyllosilicates or tectosilicates (classified as lithics), may be necessary for dawsonite precipitation, in addition to feldspars. Indeed, these silicate rock fragments affect the silica activity and the $\mathrm{pH}$, which are known to be crucial in dawsonite stability (Hellevang et al., 2011). On the other hand, it is observed that subarkose and arkose sandstones cannot lead to the precipitation of dawsonite consecutively to an interaction of the rock with $\mathrm{CO}_{2}$-rich brines. In fact, mineralogical compositions of the whole rocks (Table 1 ) indicate that there are more feldspars in sandstones with dawsonite than in sandstones without dawsonite, in spite of being classified as subarkoses or arkoses. There are also more aluminosilicate minerals in dawsonite bearing sandstones. Immature sandstones (with a low $\mathrm{SiO}_{2} / \mathrm{Al}_{2} \mathrm{O}_{3}$ ratio in aluminosilicates) seem consequently more adequate for dawsonite precipitation. Conversely, natural analogues suggest that no dawsonite can be expected in mature sandstones (with a high $\mathrm{SiO}_{2} / \mathrm{Al}_{2} \mathrm{O}_{3}$ ratio).

Together with a diagram of the thermodynamic stability and the content of reactive minerals in the total rocks, this type of Folk's diagram compiling a set of natural $\mathrm{CO}_{2}$ storage analogues seems interesting to evaluate the pertinence of introducing dawsonite to simulate the long-term interaction between a determined saline sandstone aquifer and $\mathrm{CO}_{2}$. This diagram is further used for the selection of the minerals introduced in Ketzin, In-Salah and Snøhvit $\mathrm{CO}_{2}$ storage site simulations.

\subsection{Modeling aspects inherent to high salinity waters}

\subsubsection{Simulation code and activity models}

In this study, the calculations were performed using the PHREEQC v2.18 code (Parkhurst and Appelo, 1999). PHREEQC is a computer program for simulating chemical reactions and transport processes in natural water systems. PHREEQC v2.18 allows high salinity solutions to be considered, such as sedimentary basin brines, using the Pitzer formalism as activity model. When concentrated solutions are considered, the solution ideality assumption is no longer valid and an activity coefficient is used to account for deviations from ideal behavior. Debye-Hückel (Debye and Hückel, 1923), extended Debye-Hückel, or Davies activity models are the most often used to calculate the activity coefficients. These models can provide an excellent description of the interactions occurring between solutes in solutions with an ionic strength lower than 0.5 to $0.7 \mathrm{M}$. In the case of higher concentrated solutions, the B-dot model (Helgeson et al., 1969), an extension of the Debye-Hückel model, can be used for $\mathrm{NaCl}$ dominant solutions. However, the more adequate formalism to consider the solution ideality deviation at high salinities is the Pitzer formalism (Pitzer et al., 1973; Pitzer, 1991). The Pitzer model considers both the electrostatic interactions between ions and the specific interactions between ion 
pairs and triplets. These interactions amongst ions and solvent are introduced in Pitzer equations through linear combinations of parameters of a virial expansion of the excess Gibbs free energy. The determination of the Pitzer parameters is difficult, which limits the domain of application given the currently available thermodynamic databases.

\subsubsection{Evaluation of thermodynamic databases}

In the context of $\mathrm{CO}_{2}$ geological storage in saline aquifers envisaged in this study, the range of ionic strengths is largely above the $1.0 \mathrm{M}$ limit that "conventional" formalism can accept and the use of Pitzer equations is thus required to calculate the interaction energies within the solution. Considering Pitzer formalism is necessary to adequately predict the fluid rock interactions occurring during and after $\mathrm{CO}_{2}$ injection. Very few applications of the use of Pitzer activity coefficient models for $\mathrm{CO}_{2}$ geological storage can be found in the literature (Xu, 2008; Taberner et al., 2009). The purpose of the current study is to objectively evaluate the influence of databases and activity models on the simulation results based on the same initial data sets.

Before estimating this influence on three case-studies (Ketzin, Snøvith and In Salah), the efficiency of different thermodynamic databases to reproduce simple systems is evaluated. The solubility of simple minerals is calculated in saline solutions at different temperatures using different databases and compared with experimental data. Five thermodynamic databases are used for this comparison in simple geochemical systems. The purpose is to highlight the importance of considering Pitzer parameterization in highly saline solutions and to test the different databases including Pitzer coefficients. The six databases used in this study are: i) LLNL; ii) Thermoddem; iii) Pitzer.dat; iv) THEREDA; v) SandiaLab; and vi) SCALE2000 databases. The LLNL database corresponds to the "thermo.com.V8.R6.230" database (Johnson et al., 1992), produced by the Lawrence Livermore National Laboratory. Using the LLNL database, activity coefficients are calculated with the B-dot model. The Thermoddem database (Blanc et al., 2007, 2012), which is developed by BRGM, also uses the B-dot model to calculate the activity coefficients. The Pitzer.dat database is the default database provided with the PHREEQC code to calculate activity coefficients using Pitzer's ion interaction theory. However, the use of the Pitzer.dat database is limited since few species are considered and the temperature is limited to $25^{\circ} \mathrm{C}$. The THEREDA database (Altmaier et al., 2011) includes Pitzer interaction coefficients but on few species. In particular, the THEREDA database cannot consider Al and Si species and $\mathrm{C}$ species for temperatures different to the standard temperature. The SandiaLab database corresponds to the "data0.ypf.R2" Pitzer database produced in the Yucca Mountain Project (USDOE, 2007) by the Sandia National Laboratory and reformatted to the PHREEQC format by Quintessa (Benbow et al., 2008). Finally, the SCALE2000 Pitzer database (Azaroual et al., 2004) has 
been developed at BRGM for high saline solutions and brines (up to $300 \mathrm{~g} \mathrm{~L}^{-1}$ ) at high pressure and temperature conditions. The last two Pitzer databases, i.e. the SandiaLab and SCALE2000 databases, contain most species of interest for performing calculations in deep saline sedimentary environments. However, the establishment of Pitzer databases is still on-going and there are no Pitzer interaction coefficients available for all species (e.g. for Al in the SCALE2000 database), or are valid only for a limited range of temperatures (e.g. many species have only interaction coefficients at $25^{\circ} \mathrm{C}$ in the SandiaLab database), or incoherencies can be observed between the data. In particular, redox issues cannot be addressed using Pitzer databases since no interaction parameters describing the electron behavior in saline solutions are available at the present time. An attempt to deal with redox reactions in saline solutions using $\mathrm{O}_{2}$ fugacity rather than electron activity has been undertaken by Marion et al. (2003). However, formalisms for redox reactions involving $\mathrm{O}_{2}$ and related Pitzer interaction coefficients have not been introduced in the available databases. As a consequence, species which behavior is highly dependent to the redox, in particular Fe and $\mathrm{S}$ systems, cannot been considered in models when Pitzer formalism is used.

As a result, none of the currently available databases is totally appropriate for the purpose of the present study. Therefore, several databases are used to evaluate the uncertainties associated with the activity coefficient models. The comparison of the results calculated using these different databases with experimental data of simple mineral solubilities enables the accuracy of the different databases to be evaluated. Solubility measurements as a function of solution molarity were obtained from the literature for gibbsite in $\mathrm{NaCl}$ solutions from 30 to $70^{\circ} \mathrm{C}$ (Palmer and Wesolowski, 1992), for silica in $\mathrm{KCl}, \mathrm{CaCl}_{2}, \mathrm{MgSO}_{4}$ and $\mathrm{MgCl}_{2}$ solutions at $25^{\circ} \mathrm{C}$ (Marshall and Warakomski, 1980), for silica in $\mathrm{NaCl}$ solutions at 25 and $150^{\circ} \mathrm{C}$ (Chen and Marshall, 1982), for calcite in $\mathrm{NaCl}$ solutions at 25 and 60 ${ }^{\circ} \mathrm{C}$ (Wolf et al., 1989) and for gypsum in $\mathrm{NaCl}$ solutions at $25^{\circ} \mathrm{C}$ (Linke and Seidell, 1965). Solubilities were calculated for these minerals under the experimental conditions using the different databases previously presented. Calculations using the Pitzer.dat database were only performed for calcite and gypsum because this database does not contain Si and Al species.

As shown in Figure 2, calcite solubility as a function of solution salinity is well reproduced using the four Pitzer databases (only three databases at $60^{\circ} \mathrm{C}$ ). For the LLNL and Thermoddem databases, data reproduction is only satisfactory up to 0.5 and $1 \mathrm{~mol} \mathrm{NaCl} \mathrm{L}^{-1}$, respectively. Similarly to calcite solubility, the gypsum solubility in saline $\mathrm{NaCl}$ solutions (Figure 3 ) can only be reproduced using the Pitzer databases. Reproduction is slightly improved using Pitzer.dat and THEREDA rather than the SCALE2000 and SandiaLab databases. In Figure 4, amorphous silica solubility is calculated and compared with experimental data in $\mathrm{NaCl}$ solutions at 25 and $150{ }^{\circ} \mathrm{C}$, but also in $\mathrm{KCl}, \mathrm{CaCl}_{2}, \mathrm{MgSO}_{4}$ 
and $\mathrm{CaCl}_{2}$ saline solutions at $25^{\circ} \mathrm{C}$. Generally speaking, silica solubility experimental data are better reproduced using the SCALE2000 database. The range of dissolved silica and its trend with increasing salinity is reproduced satisfactorily with the SCALE2000 database in all solutions. Calculations using the SandiaLab database can provide satisfactory data reproduction, but strong discrepancies are also observed in some cases (in $\mathrm{NaCl}$ solutions at $150{ }^{\circ} \mathrm{C}$ and in $\mathrm{KCl}$ and $\mathrm{CaCl}_{2}$ solutions). For salinities below $1 \mathrm{~mol} \mathrm{~L}^{-1}$, experimental data are generally better reproduced using the Thermoddem database. At higher salinities, the Thermoddem database reproduces the trend of silica solubility with increasing salinity but significant discrepancies with the data are sometimes observed. Calculated silica solubility using the LLNL database remains constant with salinity. The reason of this constant silica solubility is due to the fact that the activity coefficient of uncharged species is calculated using the Setchenow equation and that the Setchenow parameter $\left(b_{i}\right)$ has a fixed value in PHREEQC (Parkhurst and Appelo, 1999). However, the Setchenow parameter is dependent on the temperature and the salt in which the uncharged species dissolves (Marshall and Chen, 1982). When this saltingout effect is considered, using the $b_{i}$ parameter determined for amorphous silica solubility in different salts and at different temperatures by Marshall and Chen (1982), the amorphous silica solubilities calculated using LLNL database as a function of the salinity are in much better agreement with the data (Figure 4). It illustrates the fact that the amorphous silica solubility evolution as a function of the salinity can be captured using a Debye-Hückel equation (Trusdell and Jones, 1974). However, it requires an adjustment of the activity coefficient equation parameter for each condition of temperature and solution composition, which limits its application to natural systems. The SandiaLab database is the only database with Pitzer interaction coefficients for Al. However, as shown in Figure 5, experimental data reproduction is not necessarily better than with other databases. Nevertheless, the trend of gibbsite solubility with increasing salinity is reproduced only when using the SandiaLab database. The evolution of the $\mathrm{Al}^{3+}$ activity coefficient as a function of salinity shown in Figure 6 for the different databases in the same calculation conditions as in Figure 5-a indicates that Al behavior in solution depends on the presence or the absence of interaction parameters for Al. Indeed, in the Pitzer activity model formulation (Pitzer, 1991) part of the expression corresponds to an extended Debye-Hückel equation, including a dependence on the ionic strength, while the interaction parameters are involved in the other part of the expression. The differences between $\mathrm{Al}^{3+}$ activity coefficients calculated using the SandiaLab database, which includes Pitzer interaction parameters, and using the SCALE2000 database, without Pitzer interaction parameters, illustrates the influence of considering Al interaction parameters. Without interaction parameters, the calculated activity coefficient is similar to those obtained using the B-dot activity model (Figure 6). 
The comparison of calculated and measured solubilities of simple minerals as a function of salinity highlights the importance of considering Pitzer interaction parameters in saline solutions. The SCALE2000 database provides the most coherent results including different temperatures and different ionic species, despite its lack of Pitzer interaction coefficients for Al species. The SandiaLab database contains a lot of elements with associated Pitzer interaction coefficients but results can be inconsistent, as observed for some ionic species and for temperatures different to $25^{\circ} \mathrm{C}$. Despite its aspect, the SandiaLab database cannot reliably be used for many problems, in particular those considering complex interactions and at temperatures different to $25^{\circ} \mathrm{C}$. The Pitzer.dat and THEREDA databases contain few species, which considerably limits their application range. In particular, the Pitzer.dat database is unable to consider geochemical systems encountered in siliciclastic sedimentary basins and the THEREDA database is also unable to consider $C$ species as a function of temperature. These databases are not further used in this work for the case-studies of $\mathrm{CO}_{2}$ storage in saline sandstone aquifers. Among the databases without Pitzer interaction parameters, the Thermoddem database provides the best results. The Thermoddem database is further considered in the case-studies, but not the LLNL database.

\subsection{Proposed methodology}

The following methodology is proposed to assess the fluid - rock interaction occurrences due to $\mathrm{CO}_{2}$ injection in deep saline aquifers. A batch modeling approach is considered here, where no transport of elements is calculated and the geochemical system is assumed to be a "perfectly mixed reactor" in which every single chemical compound is homogeneously distributed. The modeling approach is based on 3 steps (Figure 7):

STEP 1: This first step consists in establishing the initial conditions in the aquifer by recalculating the brine composition in reservoir conditions. Once the charge balance of the sampled water has been controlled, the solution speciation is recalculated at formation temperature. In the case where an element of interest for the studied problem has not been analyzed, its content is adjusted to achieve equilibrium with a mineral phase showing evidence of equilibrium with the formation water (e.g. Al content adjusted to kaolinite equilibrium observed as the last cement formed in the rock). The saturation indices are checked to estimate what mineral phases are at equilibrium with the brine and whether these results are consistent with the mineralogical and petrological observations. The results obtained with the Thermoddem, SCALE2000 and SandiaLab databases are compared to evaluate the differences linked to databases. Note that the effect of pressure on the thermodynamic constants is not considered here to avoid introducing further uncertainties to the calculations, which can be difficult to constrain. 
STEP 2: The second step consists in introducing the perturbation into the formation brine due to the $\mathrm{CO}_{2}$ injection. The perturbation is introduced by solubilizing $\mathrm{CO}_{2}$ in the brine at a given fugacity of $\mathrm{CO}_{2}$. The fugacity of $\mathrm{CO}_{2}$ is calculated using an equation of state (Duan and Sun, 2003) for 1.5 times the initial formation fluid pressure. Indeed, the $\mathrm{CO}_{2}$ is planned to be injected at a pressure 1.5 times higher than the formation fluid pressure, at least in large reservoirs with high permeability. A mixing approach between a water acidified at the $\mathrm{CO}_{2}$ injection fugacity end-member and a non-perturbed water end-member is then used to mimic the $\mathrm{CO}_{2}$ impact at various distances from the injection well. Considering the different databases, the effect on $\mathrm{pH}$ is checked. The saturation indices are also computed to identify the mineral phases destabilized by the $\mathrm{CO}_{2}$-induced acidification.

STEP 3: This last step consists in calculating the geochemical and mineralogical evolution of the system due to the $\mathrm{CO}_{2}$ perturbation. For this purpose, a water-rock interaction model is proposed for each case-study. The goal is to quantify the mineral changes induced by the injection of $\mathrm{CO}_{2}$ and, in particular, those contributing to $\mathrm{CO}_{2}$ mineral trapping. Special attention is paid to the influence of the database on the calculation results. These interaction models are based on the characterization of the geochemical system for the different saline sandstone aquifers (step 2) and the identification of the minerals expected to dissolve or to precipitate, in agreement with the conceptual model previously presented (cf. section 2.1). The reactions introduced into the interaction model are summarized in Table 3. Dissolution of primary aluminosilicate minerals is kinetically controlled while thermodynamic equilibrium governs the precipitation of secondary phases. Kinetics are introduced for aluminosilicate dissolution because alteration of these mineral phases may last over very long time periods and equilibrium assumptions are not realistic. On the contrary, precipitation can be considered at equilibrium over long time periods for the sake of calculation simplicity (Helgeson, 1968). Precipitation is then controlled by the release of cations by dissolution of primary minerals (see section 2.1). Kinetics are introduced through a general transition state theory law using Arrhenius-type rate equations (Lasaga et al., 1994), which may be expressed as:

$$
\frac{d m}{d t}=-A(1-\Omega) m\left(k_{\text {acid }}^{25} e^{-\frac{E_{\text {acid }}}{R}\left(\frac{1}{T}-\frac{1}{298.15}\right)} a_{H^{+}}^{n}+k_{\text {neutral }}^{25} e^{-\frac{E_{\text {neutral }}}{R}\left(\frac{1}{T}-\frac{1}{298.15}\right)}\right)
$$

where, $A$ is the reactive surface area $\left(\mathrm{m}^{2} \mathrm{~mol}^{-1}\right), k^{25}$ are the reaction rate constants for acid and neutral mechanisms at $25^{\circ} \mathrm{C}\left(\mathrm{mol} \mathrm{m}^{-2} \mathrm{~s}^{-1}\right), E$ are the activation energies $\left(\mathrm{J} \mathrm{mol}^{-1}\right), R$ is the gas constant, $T$ is the temperature (K), $a_{H+}$ is the proton activity, $n$ is an empirical exponential term, $m$ is the amount of considered mineral $(\mathrm{mol})$ and $\Omega$ is the saturation state corresponding to the ratio between the ion activity product and the thermodynamic equilibrium constant. The reaction rates and 
activation energies used in these calculations come from the compilation by Palandri and Kharaka (2004). Table 4 summarizes these parameters together with the reactive surface areas used for the different minerals. Important differences are usually observed between the dissolution rates measured in laboratory experiments, such as those reported by Palandri and Kharaka (2004), and long-term field dissolution rates (Steefel et al., 2005; Zhu, 2005; Gannor et al., 2007). In practice, this difference is often corrected by introducing a scaling factor of 0.001 on the reactive surface area measured on individual minerals at the laboratory scale (Gaus, 2005). Such a scaling factor is also used in the present calculations for the different case-studies.

Calculations were carried out over 1000 years considering the interaction between Ketzin, In Salah and Snøhvit sandstone and brines with acidified brine mixing ratios of 0, 5, 20, 50,70 and $100 \%$. The storage aquifer temperature of $36{ }^{\circ} \mathrm{C}$ was considered and the SCALE2000, SandiaLab and Thermoddem databases were used. Calculations with a non-perturbed brine correspond to a baseline case without $\mathrm{CO}_{2}$, making it possible to distinguish the brine-mineral interactions due to sandstone natural evolution from the interactions due to the $\mathrm{CO}_{2}$ intrusion.

\section{Case-studies for evaluating the long-term geochemical evolution of $\mathrm{CO}_{2}$ in saline aquifers}

\subsection{Ketzin}

\subsubsection{Site presentation}

Ketzin is an onshore site located in the Northeast German Basin for pilot injection of $\mathrm{CO}_{2}$ into an $80 \mathrm{~m}$ thick saline sandstone aquifer (Förster et al., 2006). The Ketzin injection project was funded by the European Commission under the FP6 framework (CO2SINK Project). A modest amount of $\mathrm{CO}_{2}$ was injected (60,000 tons) into an anticlinal structure of the Triassic Stuttgart Formation located at a depth of about $650 \mathrm{~m}$ above a salt pillow situated deeper (Figure 8). The Stuttgart Formation is of fluvial origin and exhibits a heterogeneous lithology showing alternations of mudstones, siltstones and fluvial sandstones (Förster et al., 2006, 2010). This formation has good reservoir properties, with an average porosity of $23 \%$ and a permeability of 50 to $100 \mathrm{mD}$ (Wiese et al., 2010). Reservoir temperatures of 33 and $36{ }^{\circ} \mathrm{C}$ were measured at depths of 600 and $700 \mathrm{~m}$, respectively. Formation pressure at $700 \mathrm{~m}$ depth is determined to range between 70 and 75 bars. The brines sampled in the formation have a salinity of about $230 \mathrm{~g} \mathrm{~L}^{-1}$ (Würdermann et al., 2010). The Stuttgart formation is overlaid by mudstones of the Weser and Arnstadt formations, which form a $210 \mathrm{~m}$ thick caprock section (Förster et al., 2006). At Ketzin experimental site, food grade $\mathrm{CO}_{2}$ (purity $99.9 \%$ ) and $\mathrm{CO}_{2}$ from an oxyfuel pilot plant (purity 99.7\%) were injected (Martens et al., 2012). 


\subsubsection{STEP 1: Initial reservoir conditions at the Ketzin site}

A detailed characterization of the Ketzin site has been carried out before injecting $\mathrm{CO}_{2}$ (Förster et al., 2006). In particular, the evaluation of the water - rock interactions at the initial state in the Stuttgart Fm can be confidently addressed since several water sampling analyses (Würdermann et al., 2010) and a detailed mineralogical and petrological analysis (Förster et al., 2010) are available. Formation water was sampled (Würdermann et al., 2010) after pumping several times the borehole volume to obtain a water sample representative of the formation. The composition of water once the borehole volume was pumped 6.8 times (KTZI 202, No 26) is reported in Table 2 and used in this study. Waters sampled after 5 times or more the borehole volume was pumped have similar compositions. Fluorescein was used as a tracer to ensure the sampled waters were not perturbed by the drilling mud (Würdermann et al., 2010). Stuttgart Fm water has a total dissolved solids (TDS) content of about $235 \mathrm{~g} \mathrm{~L}^{-1}$ and is mainly composed of $\mathrm{Na}$ and $\mathrm{Cl}$, with noticeable amounts of $\mathrm{Ca}, \mathrm{SO}_{4}$ and $\mathrm{Fe}$. Note that Al content was not determined. Charges are balanced within the solution, which has a 1.4 $\%$ error.

At Ketzin, the Stuttgart Fm presents channel and overbank facies, respectively corresponding to interbedded sandstones and thin mudstone and coal layers. Mineralogy composition is obtained from Förster et al. (2010). Quartz content ranges from 30 to 40 \%. The sandstone has a high feldspar content (from 20 to $40 \%$ ), mainly plagioclase but also K-feldspar. Mg-, Fe-, K-sheet minerals, including chlorite, illite, mixed layered illite/smectite and micas are also present in the sandstone at relatively important amounts (between 10 and $15 \%$ ). These phyllosilicates can be detrital or authigenic minerals. Amongst the authigenic minerals, analcime (a Na-zeolite) and anhydrite are the most frequent and most abundant phases. Further authigenic minerals observed at low amounts, but not in all samples, are feldspar, quartz, ferric iron oxides, clay minerals and dolomite. Petrological observations, in particular with regards to the mineral crystallinity state or the presence of dissolution footprints and overgrowths, give reliable information on the equilibrium of the mineral phases respectively to the brine in the formation conditions. At Ketzin (Förster et al., 2010), feldspar grains are partially or totally altered and replaced by illite or by other authigenic cements. An albitization of K-feldspar and plagioclase also occurred as an early diagenetic process. Lithics are strongly altered, mainly the illite and chlorite-rich grains and the feldspar-rich rock fragments. The first minerals to precipitate during diagenesis were quartz, albite and iron oxides. These precipitations were followed by precipitations of clay minerals and analcime. Dolomite then precipitated, followed by anhydrite as the latest authigenic mineral. 
The last aluminosilicate minerals to precipitate were illite and analcime and, even if these phases are not the last phases to precipitate during diagenesis, they do not show dissolution footprints. Illite can then be considered at equilibrium with the actual fluids circulating in the formation. Based on this hypothesis, Al content is adjusted to achieve solution equilibrium with illite (Mg-illite for the SCALE2000 and Thermoddem databases and Mg, K-illite for the SandiaLab database). When the solution speciation is recalculated at the formation temperature $\left(36^{\circ} \mathrm{C}\right), \mathrm{pH}$ values of $6.40,6.36$ and 6.32 are obtained with the SCALE2000, SandiaLab and Thermoddem databases, respectively. These values are close to the $6.40 \mathrm{pH}$ value measured during sampling (Table 2). Carbon dioxide fugacity log values of $-1.86,-1.92$ and -1.86 are calculated using the different databases. This narrow range of $\mathrm{CO}_{2}$ fugacities can be compared with the $\mathrm{CO}_{2}$ fugacity values measured in sedimentary basins and reported as a function of temperature by Coudrain-Ribstein et al. (1998). Calculated $\mathrm{CO}_{2}$ fugacity values for the Ketzin injection site at a temperature of $36{ }^{\circ} \mathrm{C}$ are in the range of typical $\mathrm{CO}_{2}$ fugacity in sedimentary formations for the corresponding temperature. This comparison suggests that the measured $\mathrm{pH}$ value is reliable and that the carbonate system is reliably constrained for this casestudy. Indeed, the $\mathrm{pH}$ and carbonate system can be easily altered during sampling in a deep formation, mainly because of $\mathrm{CO}_{2}$ outgassing.

Figure 9 shows the saturation indices of calcite, dolomite (medium-ordered dolomite), microcline, albite (low-ordered albite), anorthite, a Mg-chlorite (clinochlore), a Na-zeolite (analcime), quartz, anhydrite, kaolinite and dawsonite calculated using the SCALE2000, SandiaLab and Thermoddem databases. Stuttgart Fm porewater, with Al content adjusted to achieve illite equilibrium, is close to equilibrium with microcline, albite, analcime, quartz, anhydrite and dawsonite. A good agreement between databases is observed for these phases. Dolomite is slightly oversaturated when using the SCALE2000 and SandiaLab databases but undersaturated using the Thermoddem database. A similar difference in saturation state is obtained for kaolinite, which is oversaturated according to the SandiaLab and Thermoddem databases but is undersaturated using the SCALE2000 database. Anorthite and clinochlore are strongly undersaturated with the three databases. However, an important difference is observed between clinochlore saturation indices calculated with the SCALE2000 database and using the SandiaLab and Thermoddem databases. One can then expect different evolutions of the system after $\mathrm{CO}_{2}$ perturbation, depending on the database.

\subsubsection{STEP 2: Acidification of Ketzin brine by $\mathrm{CO}_{2}$}

In this second step, the effect of $\mathrm{CO}_{2}$ on the formation brine is simulated, without considering interactions with the rock at this stage. Under the injection pressure (1.5 times the formation pressure of about 75 bars) and temperature $\left(36^{\circ} \mathrm{C}\right)$ conditions at the Ketzin injection site, $\mathrm{CO}_{2}$ 
fugacity is 56.8 bars. The initial formation brine is equilibrated with such a $\mathrm{CO}_{2}$ fugacity to calculate the brine composition and speciation with maximal $\mathrm{CO}_{2}$ perturbation. Several mixings between $\mathrm{CO}_{2}-$ perturbed (100\%) and non-perturbed (0\%) end-member brines are then computed, leading to brines acidified at different levels.

Speciation, $\mathrm{pH}$ and saturation indices are calculated for the different resulting solutions using the SCALE2000, SandiaLab and Thermoddem databases (Figure 10). pH calculations show a decrease from about 6.4 for the non-perturbed brine to about 3.1 with the SCALE2000 and Thermoddem databases or 4.39 with the SandiaLab database for the acidified brine. $\mathrm{pH}$ strongly decreases even for solutions with low percent of acidified brines. Indeed, for a $5 \%$ acidified brine ratio the $\mathrm{pH}$ is calculated at 4.21, 4.13 and 6.07 using the SCALE2000, Thermoddem and SandiaLab databases, respectively. This decrease is to be compared with the increase in $\mathrm{CO}_{2}$ fugacity observed for mixed solutions. In Figure 10, calcite has been elected to show the carbonate mineral saturation index evolution and microcline for the aluminosilicate minerals. Saturation indices of these different minerals are calculated to strongly decrease when acidified brines are considered, because of the $\mathrm{pH}$ decrease. A decrease in saturation index is observed both for silicate and carbonate minerals, in spite of the increase in dissolved carbonate content. Differences in saturation index evolution are observed between the different databases. Higher saturation indices are calculated using the SandiaLab database for which higher $\mathrm{pH}$ are calculated. Differences in saturation index are also related to the considerations of ion interactions, since differences are observed between the SCALE2000 and Thermoddem databases, although pH are similar in both calculations.

\subsubsection{STEP 3: Evaluation of $\mathrm{CO}_{2}$ - water - rock interactions at Ketzin by batch modeling}

This step aims at estimating the long-term geochemical and mineralogical interactions between the $\mathrm{CO}_{2}$ perturbed brine and Ketzin injection site sandstone. An interaction model is proposed for the Ketzin site, based on the sandstone aquifer mineralogy and the observations derived from $\mathrm{CO}_{2}$ storage natural analogues and laboratory experiments, presented in section 2.1. Ketzin sandstone has an important content in feldspars and aluminosilicate minerals such as chlorite, illite and zeolite (Förster et al., 2010). As indicated by the feldspar alteration observations, feldspars are unstable under present-day conditions in the formation. Feldspars are all the more unstable when the brine is acidified as a consequence of $\mathrm{CO}_{2}$ introduction (Figure 10) and microcline saturation indices indicate that microcline is slightly more unstable than plagioclase. Chlorite (clinochlore) also shows alteration indications and is calculated to be strongly undersaturated in initial Ketzin brine (Figure 9) and in acidified brines (Figure 10). Illite and analcime precipitated during sandstone diagenesis and are 
considered at equilibrium with the aquifer porewater (Figure 9 and section 3.1.2). These aluminosilicates were identified in section 2.1 as reactive phases likely to dissolve as a result of interaction with $\mathrm{CO}_{2}$-rich water and saturation indices calculated for the $\mathrm{CO}_{2}$ perturbed Ketzin brine indicate that these phases are unstable when a $\mathrm{CO}_{2}$ perturbation is considered (Figure 10). Microcline has been selected as reactive feldspar because this phase is abundant in Ketzin sandstone and is already partially altered and, consequently, more sensitive to another perturbation. Microcline, clinochlore, analcime and Mg-illite are then introduced in the interaction model as phases that can dissolve (Table 3). With regards to the minerals that can precipitate as a result of high $\mathrm{CO}_{2}$ content in water and the dissolution of primary minerals, kaolinite, quartz or chalcedony and carbonate minerals were identified in section 2.1 to precipitate in almost all natural analogues and during laboratory experiments. Kaolinite, chalcedony and dolomite are then introduced into the interaction model for Ketzin as phases allowed to precipitate. Chalcedony has been preferred over quartz because it can form more easily and is often observed as secondary silica phase. Dolomite has been selected because precipitations of $\mathrm{Ca}, \mathrm{Mg}$ (and $\mathrm{Fe}$ ) carbonates are generally observed in the natural analogues rather than pure $\mathrm{Ca}$ or $\mathrm{Mg}$ carbonates. Furthermore, $\mathrm{Mg}$ is expected to be released in solution if clinochlore and Mg-illite dissolve. In addition to these secondary phases, dawsonite is also introduced into the $\mathrm{CO}_{2}$-water-rock model for Ketzin as a potential secondary phase. This choice has been made because Ketzin sandstone has large amounts of reactive aluminosilicate minerals and sandstones with similar composition that have been subject to $\mathrm{CO}_{2}$ perturbation exhibit dawsonite precipitation.In particular, Ketzin sandstone has a composition similar to the sandstone of the Songliao Basin analogue where dawsonite has been observed (Liu et al., 2011). At Ketzin reservoir temperature $\left(36{ }^{\circ} \mathrm{C}\right)$, dawsonite precipitation can perhaps be slow (Hellevang et al., 2011), but dawsonite precipitation has been observed in natural analogues for temperatures ranging for 25 to $120^{\circ} \mathrm{C}$ and can then take place at Ketzin.

Calculation results for the Ketzin injection site are shown in Figure 11, where the cumulated mineral evolution over 1000 years is expressed as variations in mineral \%wt within the rock. Analcime is the main mineral to dissolve as a result of sandstone interaction with $\mathrm{CO}_{2}$-rich brine. Up to $2 \%$ of analcime is calculated to dissolve for the acidified brine. Analcime dissolution is less important when a mix of initial and acidified brines is considered and its dissolution increases regularly with the ratio of acidified brine. Other minerals allowed to dissolve evolve at low and non-representative amounts. A maximum of $0.016 \%$ of illite is predicted to dissolve while less than $0.0001 \%$ of clinochlore and $0.000008 \%$ of microcline are calculated to dissolve (not shown in Figure 11). The main simulated precipitations are chalcedony and dawsonite (up to $1 \%$ each for the acidified brine). Dissolved and precipitated amounts increase regularly with the ratio of acidified brine. Some differences in the 
results are observed between the different databases. A little more analcime is calculated to dissolve using the SandiaLab database and a little more chalcedony also precipitates. Using the SandiaLab database, limited amounts of dolomite and kaolinite are also calculated to precipitate, while these minerals are not observed (or at very small amounts) with the two other databases. More noticeable differences between databases then occur for minerals precipitating or dissolving at very limited amounts. When the initial brine is considered, mineralogy does not evolve or does so to a very limited extent.

Regarding the evolution of the modeled system over time, in the present batch conditions without sustaining the $\mathrm{CO}_{2}$ perturbation, aluminosilicate saturation indices become positive or null after relatively few dissolution steps. Dissolution then stops or becomes very limited after several tens of years. The time needed to reach system equilibrium tends to increase when more acidified brines are considered. Brine $\mathrm{pH}$ values increase during system evolution and these values are similar once system equilibrium is reached, whatever the acidified brine mixing ratio of the solution. Final $\mathrm{pH}$ values are 6.30, 7.46 and 6.66 using the SCALE2000, SandiaLab and Thermoddem databases, respectively. Solute component contents remain relatively stable over system evolution with a small increase in $\mathrm{Al}$ and $\mathrm{Mg}$, but most components released by aluminosilicate dissolution are calculated to reprecipitate. Even the decrease in carbonate content due to dawsonite and dolomite precipitation tends to be limited.

\subsection{In Salah}

\subsubsection{Site presentation}

In Salah is located in the Sahara desert in Algeria and the methane production and $\mathrm{CO}_{2}$ injection project is developed jointly by BP, Statoil and Sonatrach at the Carboniferous Krechba gas field. The produced gas contains up to $10 \%$ of $\mathrm{CO}_{2}$ while export sales require concentrations less than $0.3 \%$. To achieve this limit, $17 \mathrm{Mt}$ of $\mathrm{CO}_{2}$ have been separated and geologically stored over 20 years since 2004. At the In Salah site (Figure 8), a $20 \mathrm{~m}$ thick sandstone of Tournaisian age known as ' $\mathrm{C} 10^{\prime}$ sandstone forms the principal reservoir in an anticlinal structure for gas production but also for $\mathrm{CO}_{2}$ injection. It is overlaid by over $950 \mathrm{~m}$ of Carboniferous mudstones forming an efficient seal. The producing wells are located in the hydrocarbon gas column on the crest of the structure and $\mathrm{CO}_{2}$ is injected through 3 wells on the flanks of the reservoir, below the gas - water contact. The reservoir lies at depths of around $1800 \mathrm{~m}$ below the surface and comprises fine-grained quartzose sandstones. According to the site description given within the CO2ReMoVe FP6 European project (Wildenborg et al., 2009; Vong et al., 2010), porosities range from 13 to $20 \%$ and permeabilities are highly variable 
as a function of the chlorite content, but average around $10 \mathrm{mD}$. Temperature and pressure in the reservoir are about $96{ }^{\circ} \mathrm{C}$ and 180 bars, respectively. Brine salinity is about $170 \mathrm{~g} \mathrm{~L}^{-1}$, with $\mathrm{Na}$, Ca and $\mathrm{Cl}$ as main components. The injected gas is composed of $\mathrm{CO}_{2}$ at concentrations higher than $99 \%$ and by trace amounts of methane, nitrogen and other components (including heavy alkanes, benzene and toluene).

\subsubsection{STEP 1: Initial reservoir conditions at the In Salah site}

The composition of a water sample taken in November 2004 at the bottomhole of one of the $\mathrm{CO}_{2}$ injection wells (Kb502) has been provided through the CO2ReMoVe project as representative of the 'C10' Tournaisian sandstone porewater (Table 2). This water has a TDS of about $175 \mathrm{~g} \mathrm{~L}^{-1}$ and is mainly composed of $\mathrm{Na}, \mathrm{Ca}$ and $\mathrm{Cl}$, with noticeable amounts of $\mathrm{Mg}$. Note that the $\mathrm{Al}$ content is missing for this water. Solution electroneutrality is achieved, with an error of less than $0.1 \%$.

The Tournaisian sandstone at the In Salah injection site is mainly composed of quartz (between 69.9 and $88.5 \%$ ). Further detrital phases are mica and illite (about $5 \%$ ). the main authigenic minerals are Fe-rich chlorite (from 5 to $10 \%$ ) and siderite (from 1.2 to $11.7 \%$ ). Small amounts (less than $1 \%$ each) of pyrite, dolomite and kaolinite also compose the In Salah reservoir. Diagenesis consisted first in cementation of chlorite, siderite, Fe-dolomite and pyrite. This first cementation was followed by chalcedony precipitation and, then, by a dissolution event which mainly affected the detrital clays, chlorite and pyrite. The last observed diagenetic event was a minor precipitation of kaolinite.

As the last authigenic mineral to precipitate, kaolinite can be assumed to be at equilibrium with present-day formation water. Therefore, the missing Al content is adjusted to achieve kaolinite equilibrium. Solution speciations recalculated at reservoir temperature $\left(96^{\circ} \mathrm{C}\right)$ with the SCALE2000, SandiaLab and Thermoddem databases give $\mathrm{pH}$ values of 5.55, 5.16 and 5.33, while the $\mathrm{pH}$ value measured after sampling is 5.20 (Table 2). Calculated carbon dioxide fugacities are similar, with log values of $-0.57,-0.51$ and -0.49 using the SCALE2000, SandiaLab and Thermoddem databases, respectively. These values are in the range of $\mathrm{CO}_{2}$ fugacities measured in sedimentary basins for a temperature corresponding to the In Salah reservoir temperature (Coudrain-Ribstein et al., 1998), suggesting $\mathrm{pH}$ and carbonate system are reliable for the In Salah formation water.

Figure 12 shows the saturation indices calculated at $98^{\circ} \mathrm{C}$ with Al content set at kaolinite equilibrium using the different databases for calcite, dolomite, illite, clinochlore, quartz, anhydrite and dawsonite. According to these calculations, calcite, dolomite, quartz and anhydrite are close to equilibrium in the brine. Illite, clinochlore and dawsonite equilibrium states are uncertain because of differences between databases. A good agreement between databases is obtained for quartz and 
anhydrite saturation indices. For calcite and dolomite, slight differences are observed but minerals are oversaturated using the SCALE2000 database and undersaturated using the SandiaLab and Thermoddem databases. Strong differences in aluminosilicate saturation indices are calculated according to the database used. The same reaction constants for illite and clinochlore are used in the SCALE2000 and Thermoddem databases but not in the Sandialab database. These differences in saturation indices are then partly due to reaction constant differences but mostly to differences related to the ion interaction treatments, as illustrated by the differences in the $\mathrm{Al}^{3+}$ activity coefficient calculated in Figure 6 depending on whether Pitzer interaction parameters for Al are considered or not. A difference in saturation indices is also observed for dawsonite, because of the differences in Al behavior in solution when the different databases are used.

\subsubsection{STEP 2: Acidification of In Salah brine by $\mathrm{CO}_{2}$}

Acidification of the In Salah injection site brine is made considering a $\mathrm{CO}_{2}$ fugacity of 143.8 bars, corresponding to the fugacity calculated for 1.5 times the 180 bars formation pressure at a temperature of $96^{\circ} \mathrm{C}$. In Figure 13, $\mathrm{pH}$ is shown to decrease from 5.55 to 3.43 using the SCALE2000 database, from 5.16 to 2.80 using the SandiaLab database and from 5.33 to 3.06 using the Thermoddem database. $\mathrm{pH}$ decreases significantly even for low acidified brine ratios. Saturation indices are also calculated to decrease with respect to their initial values in the reference brine. Noticeable differences in saturation indices for acidified brines are obtained with the different databases. For $100 \%$ acidified brine, calcite saturation index is -1.2 with the SCALE2000 database, 2.4 with the SandiaLab database and -2.2 with the Thermoddem database. For illite, this difference is even more pronounced with a saturation index of around -11 with the SCALE2000 and Thermoddem databases and a saturation index of -18.5 using the SandiaLab database. Differences in saturation index increase with the percent of acidified brine. Carbon dioxide fugacities of the mixed solutions are similar using the different databases and notably increase even for solutions with the lowest acidified brine mixing ratios.

\subsubsection{STEP 3: Evaluation of $\mathrm{CO}_{2}$ - water - rock interactions at In Salah by batch modeling}

The interaction model for simulating interactions between $\mathrm{CO}_{2}$-rich brine and the sandstone at the In Salah injection site is based on the rock mineralogy. In Salah sandstone is mainly composed of quartz, which is a phase with a relatively weak reactivity. The rock forming aluminosilicate minerals expected to dissolve as a consequence of interaction with $\mathrm{CO}_{2}$-rich brine are illite, mica and chlorite. Note that there are no feldspars in this sandstone. One of the latest events during rock diagenesis was dissolution of clays and chlorite. Therefore, these phases are not at equilibrium with the brine prior 
to $\mathrm{CO}_{2}$ injection. Because of database differences, calculated saturation indices (Figure 12) cannot confirm these petrological observations. Furthermore, these phases are likely to dissolve in contact with acidified brines (Figure 13 and section 2.1). Mg-illite and clinochlore are then considered as the phases able to dissolve in the interaction model for In Salah (Table 3). Carbonate minerals (siderite and dolomite) precipitated during the rock evolution and can precipitate in $\mathrm{CO}_{2}$-rich brine when cations are released by aluminosilicate dissolution. Dolomite is then considered in the model as a mineral allowed to precipitate. Chalcedony and kaolinite are also allowed to precipitate as a consequence of illite and clinochlore dissolution (section 2.1). Dawsonite precipitation seems unlikely in In Salah sandstone. Indeed, this sandstone has little amounts of reactive minerals and the study of $\mathrm{CO}_{2}$ storage natural analogues showed that dawsonite is observed to precipitate in sandstone with elevated relative contents in aluminosilicates (section 2.1). In Figure 1, the In Salah composition is covered in the composition range of the Bowen-Gunnedah-Sydney Basin analogue. This analogue contains dawsonite but a heterogeneous composition is reported for it (Baker et al., 1995) without being precise whether dawsonite is observed for all sandstone types. Given the observations provided by other analogues, it is not very probable that dawsonite precipitates in a sandstone with In Salah sandstone composition and, therefore, it will not be considered in the interaction model.

Results of mineralogy changes calculated with the interaction model are shown in Figure 14. Important differences are observed depending on the database. Up to $3 \%$ of illite is expected to dissolve using the SandiaLab database, while approximately half this amount dissolved using the Thermoddem database and less than $0.1 \%$ of illite is found to dissolve using the SCALE2000 database. The second mineral allowed to dissolve, namely clinochlore, dissolves at limited amounts, $0.15 \%$ at a maximum, for all the databases. Precipitations are influenced by the noticeable differences in dissolution between databases. Indeed, up to $2.5 \%$ of kaolinite and up to $0.6 \%$ of chalcedony precipitate using the SandiaLab database, while about half this amount precipitates using the Thermoddem database. Using the SCALE2000 database, no kaolinite is calculated to precipitate and less than $0.1 \%$ of chalcedony precipitates. Precipitation of dolomite is also predicted, with less difference between databases. The evolution of dolomite precipitation with the increase in the acidified brine mixing ratio seems irregular, contrary to illite dissolution evolution and kaolinite and chalcedony precipitation evolutions, which are regular. No significant mineralogical modifications are simulated when the initial brine is considered in the interaction model.

In the case of In Salah $\mathrm{CO}_{2}$ injection simulation, very different results are obtained as a function of the databases. While limited mineralogical modifications are expected using the SCALE2000 database, relatively important changes are observed using the SandiaLab database. However, the 
most important differences do not concern dolomite precipitation, which contributes to $\mathrm{CO}_{2}$ mineral trapping.

The water evolution shows a $\mathrm{pH}$ increase during the simulations (Figure 14) but, contrary to the Ketzin case, different final $\mathrm{pH}$ values are obtained depending on the acidified brine mixing ratio of the initial solution. The $\mathrm{pH}$ value further increases using the database predicting the most reactive system (i.e. the SandiaLab database), up to being buffered at non-perturbed brine $\mathrm{pH}$ values for the solutions with the lowest acidified brine mixing ratios.

\subsection{Snøhvit}

\subsubsection{Site presentation}

Snøhvit is an offshore $\mathrm{CO}_{2}$ injection site located in the south western Barents Sea in Norway in the central part of the Hammerfest Basin. $\mathrm{CO}_{2}$ is re-injected after its separation from methane produced at the Snøhvit, Albatross and Askeladd fields, which contain 5 to $8 \%$ of $\mathrm{CO}_{2}$. The Snøhvit production and injection site is operated by Statoil and owned by Statoil, Petoro, Total E\&P, GDF Suez, Hess and RWE-Dea. Injection started in 2008 and about $23 \mathrm{Mt}$ of $\mathrm{CO}_{2}$ are planned to be injected over the 30 year lifespan of the project. The reservoir lithostratigraphic formations are late Triassic - Middle Jurassic formations called Fruholmen, Tubåen, Nordmela and Stø and are mainly composed of sandstones interbedded with thin shale layers (Linjordet and Grung Olsen, 1992). They are overlaid by Jurassic shale and thick Cretaceous shale caprocks (Figure 8). Natural gas is extracted from the Stø Fm reservoir and $\mathrm{CO}_{2}$ is re-injected into the Tubåen saline aquifer and into the Stø Fm since 2011 after unexpected pressure increase in the Tubåen Fm (Hermanrud et al., 2013). The Tubåen aquifer has a thickness of about 45 to $75 \mathrm{~m}$ and is situated below the Stø Fm, at a depth of $2600 \mathrm{~m}$. The Nordmela formation is sandwiched by the Tubåen and Stø formations and a shale-rich level of the Nordmela Fm acts as a caprock for the $\mathrm{CO}_{2}$ storage. The Tubåen $\mathrm{Fm}$ is dominated by sandstones with subordinate shales and minor coals. The Tubåen aquifer porosity and permeability range from 10 to $15 \%$ and 185 to $883 \mathrm{mD}$, respectively. Reservoir pressure and temperature are 285 bars and $98{ }^{\circ} \mathrm{C}$, respectively. A high salinity of about $160 \mathrm{~g} \mathrm{~L}^{-1}$ is measured in the Tubåen aquifer. The injected gas is mainly composed of $\mathrm{CO}_{2}(99.8 \%)$ with trace amounts of methane and heavy alkanes (Vong et al., 2010).

\subsubsection{STEP 1: Initial reservoir conditions at the Snøhvit site}

Relatively little information is available on the Tubåen $\mathrm{Fm}$ at $\mathrm{Sn} \varnothing \mathrm{hvit}$, where $\mathrm{CO}_{2}$ is injected. However, sufficient data for its geochemical characterization can be deduced from the overlying St $\varnothing \mathrm{Fm}$ exploited gas reservoir, which is better characterized. Some information from the St $\varnothing$ Fm can be used 
for the Tubåen Fm because no sedimentary hiatuses are observed between these two formations and because X-ray, neutron porosity and sonic logs (Linjordet and Grung Olsen, 1992) show similar trends for both formations.

The composition of a brine sampled by Statoil in the Tubåen Fm (well 7121/4-1) prior to $\mathrm{CO}_{2}$ injection is reported in Table 2. Contents in minor components such as $\mathrm{Ni}, \mathrm{Fe}$ and $\mathrm{SiO}_{2}$ were deduced by Rochelle et al. (2007) from $\mathrm{CO}_{2}$ - rock interaction experiments using Tubåen Fm sandstone. However Al content is missing in the water analysis. Tubåen Fm brine has a TDS of about $160 \mathrm{~g} \mathrm{~L}^{-1}$ and is mainly composed of $\mathrm{Na}$ and $\mathrm{Cl}$, with subordinate content in $\mathrm{Ca}$. Brine is charge balanced, with a $0.2 \%$ error.

No precise mineralogical and petrological descriptions of the Tubåen Fm sandstone are available. However the St $\varnothing$ and Tubåen formations have similar lithologies (Linjordet and Grung Olsen, 1992), with more argillaceous layers in the Tubåen Fm than in the Stø Fm. The mineralogy of the Stø Fm (Linjordet and Grung Olsen, 1992) is consequently considered here for the Tubåen Fm. Detrital minerals are mainly quartz with 80 to $90 \%$ of monocrystalline quartz, polycrystalline quartz and chert. Further detrital phases are mica, K-feldspar, plagioclase, metamorphic and sedimentary rock fragments and heavy minerals. Quartz is the main cementing material. Cement is also composed of ankerite, dolomite, calcite, kaolinite, illite and pyrite.

In the absence of a precise diagenetic evolution description, illite is assumed to be at equilibrium with the actual formation water. Indeed, kaolinite and K-feldspar are expected to react together to form illite, which is observed as an authigenic mineral in the sandstone. Missing Al content is then adjusted to achieve solution equilibrium with Mg-illite. Solution speciation is recalculated at reservoir temperature $\left(98^{\circ} \mathrm{C}\right)$ using the SCALE2000, SandiaLab and Thermoddem databases. Calculated pH at reservoir temperature $(6.19,6.11$ and 6.21 , with the respective databases) is similar to the $\mathrm{pH}$ measured at surface conditions (6.20). Carbon dioxide fugacity log values of $-0.42,-0.44$ and -0.40 are calculated using the SCALE2000, SandiaLab and Thermoddem databases, respectively. These $\mathrm{CO}_{2}$ fugacity values are in the range of measured and predicted $\mathrm{CO}_{2}$ fugacity values in sedimentary basins at Tubåen Fm temperature (Coudrain-Ribstein et al., 1998). This observation suggests that outgassing and perturbation of the carbonate system equilibrium were limited during brine sampling. This brine can consequently be considered as representative of the Tubåen Fm porewater.

Saturation indices of calcite, dolomite, microcline, albite, kaolinite, Mg-chlorite, quartz, anhydrite and dawsonite calculated using the SCALE2000, SandiaLab and Thermoddem databases are shown in Figure 15. Saturation indices of aluminosilicate minerals (kaolinite and chlorite) and dawsonite calculated for Snøhvit injection reservoir water show noticeable differences, depending on the database used for the calculations. In particular, saturation indices calculated with the SCALE2000 
database are different to saturation indices calculated using the SandiaLab and Thermoddem databases. Similar saturation indices are calculated with the three databases for further minerals shown in Figure 15 (calcite, dolomite, quartz and anhydrite). These differences concern only Albearing minerals, suggesting they are related to differences in Al behavior using the SCALE2000, SandiaLab and Thermoddem databases. Aluminosilicates are, depending on the database, slightly oversaturated to strongly oversaturated in the Tubåen Fm porewater. Calcite and dolomite are also oversaturated, while quartz is at equilibrium and anhydrite is slightly undersaturated.

\subsubsection{STEP 2: Acidification of Snøhvit brine by $\mathrm{CO}_{2}$}

For the Snøhvit injection site case-study, a $\mathrm{CO}_{2}$ fugacity of 207.9 bars is calculated considering 1.5 times the 300 bars formation pressure at a temperature of $98{ }^{\circ} \mathrm{C}$. As a consequence of brine equilibrium with such a $\mathrm{CO}_{2}$ fugacity, the $\mathrm{pH}$ value is calculated to decrease from about 6.3 to about 3.5 (Figure 16). pH values calculated with the three different databases show small differences. Small differences between databases are also noted for the calcite saturation index (Figure 16), which decreases to a minimal value of -1.6. Stronger differences are observed for aluminosilicate mineral saturation indices. For example, microcline saturation index for $100 \%$ acidified brine is -7.2 and -9.7 using the SCALE2000 and SandiaLab databases, respectively, while it is only -3.9 using the Thermoddem database. Same $\mathrm{CO}_{2}$ fugacities are calculated for a same mixing factor using the three databases.

\subsubsection{STEP 3: Evaluation of $\mathrm{CO}_{2}$ - water - rock interactions at Snøhvit by batch modeling}

The same approach as in previous case-studies is undertaken to evaluate the long-term interactions between sandstone and $\mathrm{CO}_{2}$-rich brine at the Snøhvit injection site. The Snøhvit target reservoir for $\mathrm{CO}_{2}$ injection is mainly composed of quartz, both as detrital component and as cement. Rock-forming aluminosilicate minerals likely to react with $\mathrm{CO}_{2}$-rich brine are feldspars, mica, chlorite (as metamorphic and sedimentary fragment) and illite (section 2.1). Furthermore, these minerals are undersaturated in acidified Snøhvit brine (Figure 16). In the interaction model for Snøhvit, microcline and Mg-chlorite are introduced as minerals allowed to dissolve (Table 3), following kinetic laws. Ca-, Mg- and Fe-carbonates, kaolinite and quartz are already present in the sandstone reservoir and these minerals can precipitate as a consequence of rock interaction with $\mathrm{CO}_{2}$-rich brine (section 2.1). Dolomite, kaolinite and chalcedony are allowed to precipitate in the interaction model, at equilibrium. Dawsonite is not expected to form because the Snøhvit sandstone initial composition, with little amounts of reactive minerals, does not correspond to any sandstone composition in which dawsonite is observed, according to $\mathrm{CO}_{2}$ storage natural analogues (section 2.1 and Figure 1). 
Relatively limited amounts of minerals are calculated to dissolve and precipitate in the Snøhvit case (Figure 17). At most, for the acidified brine, $0.15 \%$ of microcline and $0.07 \%$ of clinochlore dissolve. Chalcedony, dolomite and kaolinite precipitate in a similar range of proportions and at limited amounts; i.e. less than $0.1 \%$ at a maximum for each mineral. Note that no kaolinite precipitates using the SCALE2000 database, while the most important dolomite precipitations are calculated with this database. Largest microcline dissolutions are obtained using the SandiaLab database, as well as the most important chalcedony and kaolinite precipitations.

During system evolution, brine $\mathrm{pH}$ increases but its variation is lower than for the Ketzin and In Salah cases. This low pH buffering by the Snøhvit geochemical system is related to the lower reactivity of the system compared with the other case-studies. Using the different databases, $\mathrm{pH}$ values range in approximately $0.5 \mathrm{pH}$ units.

\section{Discussion}

The characterization of the baseline geochemical systems of Ketzin, In Salah and Snøhvit $\mathrm{CO}_{2}$ injection sites has highlighted three cases that are relatively different regarding their reactivity. Ketzin sandstone has high contents of reactive minerals while the two other sandstones are mainly composed of quartz. Amongst the two quartz-rich sandstones, the In Salah initial porewater is more acidic than the Snøhvit porewater, suggesting that dissolution of minerals in In Salah sandstone is likely to be more pronounced than in Snøhvit sandstone. Based on the mineralogical and petrological observations, a reactive model has been proposed for each case-study in the presence of $\mathrm{CO}_{2}$. For dissolution, these models consider mineral phases present in the rock and expected to be altered by a $\mathrm{CO}_{2}$-rich brine according to the general conceptual model based upon the laboratory experiments and natural analogue observations. Several aluminosilicates were selected for dissolution for each site but these minerals did not necessarily dissolve because the dissolution of an aluminosilicate can prevent another aluminosilicate from dissolving by switching its thermodynamic state to oversaturation. Dolomite, chalcedony and kaolinite were selected in all cases because these phases are commonly observed as secondary minerals in $\mathrm{CO}_{2}$ storage natural analogues for all sandstone compositions. Dawsonite has been selected only for the Ketzin storage site, the reservoir of which contains large proportions of reactive minerals such as zeolite, feldspars and clay minerals. The conceptual model has highlighted that the possibility of dawsonite precipitation in a sandstone consequent to $\mathrm{CO}_{2}$ seepage is strongly dependent on the sandstone composition (Figure 1). Indeed, dawsonite precipitation is rarely observed in natural analogues with high quartz contents and low clay contents but can precipitate in rocks with higher reactive mineral contents. 
These differences in apparent reactivity between case-studies leading to the establishment of different models are logically observed in the simulation results. First of all, the Snøhvit case-study was identified as having potentially a low reactivity and presents very limited mineralogical changes after 1000 years of interaction for both acidified brine mixing ratios of the reacting solutions. $\mathrm{pH}$ buffering also seems limited. The most reactive case is effectively Ketzin, for which zeolite (analcime) is the most unstable primary aluminosilicate mineral under these conditions and up to $1 \%$ of dawsonite is simulated to precipitate. Such a dawsonite precipitation after zeolite alteration is reported for the Cerro Barcino Formation $\mathrm{CO}_{2}$ storage natural analogue, where up to $25 \%$ of dawsonite is observed to precipitate (Zalba et al., 2011). A buffering of $\mathrm{pH}$ was also obtained for all degrees of $\mathrm{CO}_{2}$ perturbation. For the In Salah site using the SandiaLab database, higher amounts of primary silicates are simulated to dissolve than for the Ketzin case, but this higher dissolution is not observed with the other databases. At In Salah, the precipitation of carbonates (dolomite) is also more restricted than at Ketzin.

Chlorite (clinochlore) is observed to be the main phase to dissolve at the In Salah and Snøhvit injection sites. Chlorite has already been shown in previous studies to preferentially dissolve in thermodynamic conditions corresponding to $\mathrm{CO}_{2}$ disposal in sandstone layers (Khim et al., 2012). However, when present in the sandstone, zeolite is even more reactive than chlorite, as observed for the Ketzin site. Considering the most reactive case, only $1 \%$ of carbonate minerals are calculated to precipitate. This suggests that mineralogical changes are limited in the presence of an acidic $\mathrm{CO}_{2}$-rich brine. However, it is not possible to quantify $\mathrm{CO}_{2}$ mineral trapping with such batch calculations considering only an input of $\mathrm{CO}_{2}$ as dissolved $\mathrm{CO}_{2}$ at the beginning of the calculations (Fig. 6). Indeed, here the perturbation in $\mathrm{CO}_{2}$ is not maintained over time whereas, in a storage, the gas phase maintains high aqueous $\mathrm{CO}_{2}$ contents when dissolved $\mathrm{CO}_{2}$ is consumed by mineral reactions. In the present calculations, partial return to system equilibrium tends to consume a large proportion of the initially introduced $\mathrm{CO}_{2}$, but the reactivity is kinetically controlled and the carbonation rate will not necessarily be higher if the $\mathrm{CO}_{2}$ perturbation is maintained. Hydrodynamics also play a crucial role in $\mathrm{CO}_{2}$ behavior in a deep aquifer, including on the system reactivity. In particular, chemical dynamics can establish within the reservoir with carbonate dissolution in some parts of the reservoir and precipitation in other parts (Audigane et al., 2007; Neufeld et al., 2010). Therefore, an extrapolation of the contribution of the different trapping mechanisms from these calculations appears hazardous. In our calculations, mineral precipitation was assumed to occur at equilibrium, without kinetic constraints, for calculation time reasons and because of uncertainties in the kinetic parameters to be used for precipitation reactions. This assumption can be made since the objective of this work is to 
consider long-term reactivity (1000 years or more). Moreover, the precipitations are limited by the dissolution of the primary minerals, including during the first calculation time-steps because secondary minerals are initially undersaturated in most acidified brines, as shown in Figure 10, Figure 13 and Figure 16.

Regarding the calculation method, it is also important to point out that the dissolution kinetics introduces a correction of 0.001 on the reactive surface area. This correction is in the range of corrections commonly applied in modeling studies using laboratory kinetic data at the natural system scale, where only part of the mineral surface is involved in the fluid-rock reaction (Gaus, 2005; Zerai et al., 2006; Xu et al., 2010). The reactive surface area always shows a strong uncertainty in a calculation and the selection of the correction factor can lead to noticeable overestimations or underestimations (White and Brantley, 2003; Ganor et al., 2007).

In order to evaluate the possible effect of the thermodynamic database on the simulation results, the calculations were performed for the three case-studies using the Thermoddem, SCALE2000 and SandiaLab databases. These three databases were selected from six databases after comparing calculated mineral solubility with experimental data. This preliminary comparison exercise highlighted the importance of using the Pitzer equations (Pitzer et al., 1973) as activity model when saline solutions are considered. The B-dot activity model, such as used with the Thermoddem database, is not sufficient to represent system behavior at high salinity (typically, beyond that of standard seawater). Between the three case-studies, using a given database does not tend to systematically favor or inhibit the system reactivity with the exception that mineral changes seem perhaps more pronounced when the SandiaLab database is used. However, fundamental differences in the geochemical system behavior are observed for the In Salah and Snøhvit case-studies as a function of the database used in the calculations. For the In Salah case, an important dissolution of illite and an important precipitation of kaolinite are calculated using the SandiaLab database while no changes in the amounts of these minerals are obtained using the SCALE2000 database and the half of illite dissolution and kaolinite precipitation is calculated using the Thermoddem database. The same discrepancy is obtained for the Snøhvit case regarding microcline dissolution and kaolinite precipitation, although dissolution and precipitation occur in more limited amounts. The evaluation of the different databases presented in section 2.2.2 suggested that the SCALE2000 database generally provides the most coherent results, including for the Si system at temperatures different to $25{ }^{\circ} \mathrm{C}$. However, it should be recalled that parameters for Al species are not considered, impeding a correct representation of Al behavior in highly saline systems. The SandiaLab database contains Pitzer interaction parameters for Al allowing Al behavioral trends in solution to be reproduced, but 
with a lack of accuracy that was evidenced in our tests. This lack of accuracy in the representation of the Si and Al chemical systems in saline solutions is most likely the cause of the differences between the results obtained using the different databases. It is difficult to conclude which reactivity case obtained with the SCALE2000 and SandiaLab databases is the most relevant since both database present limitations. However, it clearly illustrates the need to use a Pitzer database which includes all relevant chemical species over large ranges of temperature. Such a database is not available at the present time and requires further developments including the determination of many missing interaction parameters and the assessment of the global coherence of the database.

Another limitation related to the use of the Pitzer activity model concerns the redox. Redox reactions cannot be considered because the electron interaction has not been parameterized in saline solutions. As a consequence, an Fe or S system including Fe- or S-bearing minerals cannot be considered in these calculations because the behavior of these species is strongly dependent on redox.

Therefore, the calculations carried out in this study show uncertainties regarding some parameters and limitations in the representativeness of the results at the reservoir scale. However, these calculations make it possible to assess the possible reactivity of the storage system and evaluate what reactions are expected over long-term periods. These calculations consist in an essential first step before performing reactive-transport calculations considering both gas and aqueous phases. Pitzer formalism has been implemented in various reactive-transport codes such as TOUGHREACT (Zhang et al., 2006) or BIO-CORE ${ }^{2 D}$ (Zhang et al., 2005). Using an adequate database, accurate simulations of geochemical evolution due to $\mathrm{CO}_{2}$ injection can then be carried out, including multiphase-flow in the geological media geometry.

\section{Conclusion}

The aim of this work was to improve the constraint on two aspects determining the confidence in geochemical modeling of $\mathrm{CO}_{2}$ storage in deep saline sandstone aquifers, namely, the way to calculate the interactions within the brine and the selection of the reactive mineral phases. Main results include:

- The synthesis of observations of mineralogical changes in sandstones applied to a $\mathrm{CO}_{2}$ perturbation obtained from natural analogues and from laboratory experiments makes it possible to determine with good confidence the primary minerals expected to react and the minerals that are going to precipitate. 
- The proposition of a way to identify whether dawsonite, a mineral which inclusion in models is under debate, can be formed as a secondary mineral during interaction with $\mathrm{CO}_{2}$ from the initial mineralogy of the sandstone. Indeed, it has been shown from a review of observations in natural analogues that dawsonite is only observed in lithic and feldspar rich sandstones and is not observed in quartz rich sandstones. These observations can be related to the conditions of silica activity and $\mathrm{pH}$ which influence dawsonite stability.

- A method was established to assess the geochemical reactivity of the Ketzin, In Salah and Snøhvit case-studies and to evaluate the changes in mineralogy over a long-time period. Because of the mineralogical and chemical differences between these three $\mathrm{CO}_{2}$ storage sites in saline sandstone aquifers, clear differences in geochemical behavior are predicted for these case-studies, with a higher mineral trapping expected for the Ketzin site than for In Salah and Snøhvit. This method constitutes an indispensable first step before considering reservoir geometry, mass transport and more realistic gas phase behavior.

- Two kinds of aqueous speciation models and several thermodynamic databases associated with these speciation models were tested. First in a comparison with experimental data, and then for the three $\mathrm{CO}_{2}$ storage case-studies.

- Calculations using the B-dot model, an extension of the Debye-Hückel activity model, failed in reproducing simple mineral solubilities for salinities higher than $1 \mathrm{~mol} \mathrm{~L}^{-1}$ even though the saline waters are of $\mathrm{NaCl}$ type. Two B-dot model databases were tested and better results were obtained using the Thermoddem database rather than the LLNL database.

- Calculations using the Pitzer interaction model clearly improved experimental data reproduction and allowed mineral solubility to be captured as a function of salinity in a relatively good manner. However, this study also points out that few Pitzer thermodynamic databases are currently available and the two databases containing interaction coefficients for a large number of ionic species, the SCALE2000 and SandiaLab databases, cannot confidently calculate the aqueous interaction energies and reproduce mineral solubility in all the physical/chemical conditions expected to be encountered in deep sedimentary aquifers.

- More experimental developments are clearly still needed to establish coherent databases for temperature ranges from 25 to $150{ }^{\circ} \mathrm{C}$ and to perform robust geochemical simulations involving saline solutions. It is all the more important to have reliable databases given that geochemical reactivity calculations for the Ketzin, In Salah and Snøhvit case-studies show strong differences as a function of the database used in the calculations. 


\section{Acknowledgments}

This work was part of CO2ReMoVe (2006-2012) and CO2CARE (2011-2013) projects. CO2ReMoVe project is funded by the European Commission under the $6^{\text {th }}$ Framework Program for Research and Technological Development and by the In Salah Gas Joint Industry Project (BP, Statoil, Sonatrach). CO2CARE project is funded by the European Commission within the 7th Framework Program and also co-financed by an industrial consortium consisting of Statoil, Shell, TOTAL, RWE, Vattenfall, and Veolia. S. Martens (GFZ) is thanked for her comments on this paper. Two anonymous reviewers are also gratefully acknowledged for their constructive comments which notably improved this paper.

\section{References}

Altmaier, M., Brendler, V., Bube, C., Marquardt, C., Moog, H. C., Richter, A., Scharge, T., Voigt, W., and Wilhelm, S., 2011. THEREDA. Thermodynamic reference database. Final Report, GRS-265, https://www.thereda.de/.

Audigane, P., Gaus, I., Czernichowski-Lauriol, I., Pruess, K., and Xu, T., 2007. Two-dimensional reactive transport modeling of $\mathrm{CO}_{2}$ injection in a saline aquifer at the Sleipner site, North Sea. American Journal of Science 307, 974-1008.

Audigane, P., Lions, J., Gaus, I., Robelin, C., Durst, P., Van der Meer, B., Geel, K., Oldenburg, C. M., and $\mathrm{Xu}, \mathrm{T} ., 2009$. Geochemical modeling of $\mathrm{CO}_{2}$ injection into a methane gas reservoir at the K12-B Field, North Sea. In: Grobe, M., Pashin, J. C., and Dodge, R. L. Eds.), Carbon dioxide sequestration in geological media - State of the science.

Azaroual, M., Kervévan, C., Durance, M.-V., and Brochot, S., 2004. SCALE2000 (v3.1), manuel utilisateur. BRGM.

Baines, S. J. and Worden, R. H., 2004. The long-term fate of $\mathrm{CO}_{2}$ in the subsurface: natural analogues for $\mathrm{CO}_{2}$ storage. Geological Society, London, Special Publications 233, 59-85.

Baker, J. C., Bai, G. P., Hamilton, P. J., Golding, S. D., and Keene, J. B., 1995. Continental-scale magmatic carbon dioxide seepage recorded by dawsonite in the Bowen-Gunnedah-Sydney Basin system, eastern Australia. Journal of Sedimentary Research 65, 522-530. 
Benbow, S. J., Metcalfe, R., and Wilson, J. C., 2008. Pitzer databases for use in thermodynamic modeling. Quintessa.

Benson, S. M., and Cole, D. R., 2008. $\mathrm{CO}_{2}$ sequestration in deep geological formations. Elements 4 , 325-331.

Bénézeth, P., Palmer, D. A., Anovitz, L. M., and Horita, J., 2007. Dawsonite synthesis and reevaluation of its thermodynamic properties from solubility measurements: Implications for mineral trapping of $\mathrm{CO}_{2}$. Geochimica et Cosmochimica Acta 71, 4438-4455.

Blanc, P., Lassin, A., and Piantone, P., 2007. Thermoddem a database devoted to waste minerals. http://thermoddem.brgm.fr. BRGM, Orléans, France.

Blanc, P., Lassin, A., Piantone, P., Azaroual, M., Jacquemet, N., Fabbri, A., and Gaucher, E. C., 2012. Thermoddem: A geochemical database focused on low temperature water/rock interactions and waste materials. Applied Geochemistry 27, 2107-2116.

Cantucci, B., Montegrossi, G., Vaselli, O., Tassi, F., Quattrocchi, F., and Perkins, E. H., 2009. Geochemical modeling of $\mathrm{CO}_{2}$ storage in deep reservoirs: The Weyburn Project (Canada) case study. Chemical Geology 265, 181-197.

Chen, C.-T. A. and Marshall, W. L., 1982. Amorphous silica solubilities-IV. Behavior in pure water and aqueous sodium chloride, sodium sulfate, magnesium chloride, and magnesium sulfate solutions up to $350^{\circ} \mathrm{C}$. Geochimica et Cosmochimica Acta 46, 279-288.

Coudrain-Ribstein, A., Gouze, P., and de Marsily, G., 1998. Temperature-carbon dioxide partial pressure trends in confined aquifers. Chemical Geology 145, 73-89.

Czernichowski-Lauriol, I., Rochelle, C., Gaus, I., Azaroual, M., Pearce, J., and Durst, P., 2006. Geochemical interactions between $\mathrm{CO}_{2}$, pore-waters and reservoir rocks. Advances in the Geological Storage of Carbon Dioxide. In Lombardi, S., Altunina, L. K., and Beaubien, S. E. (Eds.), NATO Science Series: IV: Earth and Environmental Sciences 65, 157-174.

Debye, P. and Hückel, E., 1923. The theory of electrolytes. I. Lowering of freezing point and related phenomena. Physikalische Zeitschrift 24, 185-206.

Dethlefsen, F., Haase, C., Ebert, M., and Dahmke, A., 2011. Uncertainties of geochemical modeling during $\mathrm{CO} 2$ sequestration applying batch equilibrium calculations. Environmental Earth Sciences, 1-13.

Duan, Z. and Sun, R., 2003. An improved model calculating $\mathrm{CO}_{2}$ solubility in pure water and aqueous $\mathrm{NaCl}$ solutions from 273 to $533 \mathrm{~K}$ and from 0 to 2000 bar. Chemical Geology 193, 257-271. 
Förster, A., Norden, B., Zinck-Jørgensen, K., Frykman, P., Kulenkampff, J., Spangenberg, E., Erzinger, J., Zimmer, M., Kopp, J., Borm, G., Juhlin, C., Cosma, C.-G., and Hurter, S., 2006. Baseline characterization of the CO2SINK geological storage site at Ketzin, Germany. Environmental Geosciences 13, 145-161.

Förster, A., Schöner, R., Förster, H. J., Norden, B., Blaschke, A. W., Luckert, J., Beutler, G., Gaupp, R., and Rhede, D., 2010. Reservoir characterization of a $\mathrm{CO}_{2}$ storage aquifer: The Upper Triassic Stuttgart Formation in the Northeast German Basin. Marine and Petroleum Geology 27, 21562172.

Ganor, J., Lu, P., Zheng, Z., and Zhu, C., 2007. Bridging the gap between laboratory measurements and field estimations of silicate weathering using simple calculations. Environmental Geology 53, 599-610.

Gao, Y., Liu, L., and Hu, W., 2009. Petrology and isotopic geochemistry of dawsonite-bearing sandstones in Hailaer basin, northeastern China. Applied Geochemistry 24, 1724-1738.

Gaus, I., 2010. Role and impact of $\mathrm{CO}_{2}$-rock interactions during $\mathrm{CO}_{2}$ storage in sedimentary rocks. International Journal of Greenhouse Gas Control 4, 73-89.

Gaus, I., Azaroual, M., and Czernichowski-Lauriol, I., 2005. Reactive transport modelling of the impact of $\mathrm{CO}_{2}$ injection on the clayey cap rock at Sleipner (North Sea). Chemical Geology 217, 319-337.

Hangx, S. J. T. and Spiers, C. J., 2009. Reaction of plagioclase feldspars with $\mathrm{CO}_{2}$ under hydrothermal conditions. Chemical Geology 265, 88-98.

Haszeldine, R., S., Quinn, O., England, G., Wilkinson, M., Shipton, Z., K., Evans, J., P., Heath, J., Crossey, L., Ballentine, C., J., and Graham, C., M., 2005. Analogues géochimiques naturels pour le stockage du dioxyde de carbone en réservoir géologique poreux profond : perspective pour le Royaume-Uni. Oil \& Gas Science and Technology - Rev. IFP 60, 33-49.

Helgeson, H. C., 1968. Evaluation of irreversible reactions in geochemical processes involving minerals and aqueous solutions I. Thermodynamic relations. Geochimica et Cosmochimica Acta $32,853-877$.

Helgeson, H. C., Brown, T. H., and Leeper, R. H., 1969. Handbook of theoretical activity diagrams depicting chemical equilibria in geologic systems involving an aqueous phase at one Atm and 0 to $300^{\circ} \mathrm{C}$. Freeman, Cooper \& Company, $253 \mathrm{pp}$.

Hellevang, H., Aagaard, P., Oelkers, E. H., and Kvamme, B., 2005. Can Dawsonite Permanently Trap $\mathrm{CO}_{2}$ ? Environmental Science \& Technology 39, 8281-8287. 
Hellevang, H., Declercq, J., Kvamme, B., and Aagaard, P., 2010. The dissolution rates of dawsonite at $\mathrm{pH} 0.9$ to 5 and temperatures of 22,60 and $77^{\circ} \mathrm{C}$. Applied Geochemistry 25, 1575-1586.

Hellevang, H., Declercq, J., and Aagaard, P., 2011. Why is Dawsonite Absent in $\mathrm{CO}_{2}$ Charged Reservoirs? Oil Gas Sci. Technol. - Rev. IFP Energies nouvelles 66, 119-135.

Hermanrud, C., Eiken, O., Hansen, O.R., Nordgaard Bolaas, H., Simmenes, T., Teige, G., Hansen, H. and Johansen, S., 2013. Importance of pressure management in $\mathrm{CO}_{2}$ storage. 2013 Offshore Technology Conference, May 06 - 09, 2013 2013, Houston, TX, USA

IPCC, 2007. Special report on carbon dioxide capture and storage. Special report of the Intergovernmental Panel on Climate Change - Summary for Policymakers and technical summary. Intergovernmental Panel on Climate Change.

Johnson, J. W., Nitao, J. J., and Knauss, K. G., 2004. Reactive transport modelling of $\mathrm{CO}_{2}$ storage in saline aquifers to elucidate fundamental processes, trapping mechanisms and sequestration partitioning. Geological Society Special Publications 233, 107-128.

Johnson, J. W., Nitao, J. J., Steefel, C., and Knauss, K. G., 2001. Reactive transport modelling of geological $\mathrm{CO}_{2}$ sequestration in saline aquifers; the influence of intra-aquifer shales and the relative effectiveness of structural, solubility and mineral trapping during prograde and retrograde sequestration. First Annual Conference on Carbon Sequestration, Washington.

Johnson, J. W., Oelkers, E. H., and Helgeson, H. C., 1992. SUPCRT92: A software package for calculating the standard molal thermodynamic properties of minerals, gases, aqueous species, and reactions from 1 to 5000 bar and 0 to $1000^{\circ} \mathrm{C}$. Computers \& Geosciences 18, 899-947.

Kaszuba, J. P., Janecky, D. R., and Snow, M. G., 2003. Carbon dioxide reaction processes in a model brine aquifer at $200{ }^{\circ} \mathrm{C}$ and 200 bars: implications for geologic sequestration of carbon. Applied Geochemistry 18, 1065-1080.

Kaszuba, J. P., Janecky, D. R., and Snow, M. G., 2005. Experimental evaluation of mixed fluid reactions between supercritical carbon dioxide and $\mathrm{NaCl}$ brine: Relevance to the integrity of a geologic carbon repository. Chemical Geology 217, 277-293.

Kaszuba, J. P., Viswanathan, H. S., and Carey, J. W., 2011. Relative stability and significance of dawsonite and aluminum minerals in geologic carbon sequestration. Geophysical Research Letters 38, L08404.

Ketzer, J. M., Iglesias, R., Einloft, S., Dullius, J., Ligabue, R., and de Lima, V., 2009. Water-rock- $\mathrm{CO}_{2}$ interactions in saline aquifers aimed for carbon dioxide storage: Experimental and numerical 
modeling studies of the Rio Bonito Formation (Permian), southern Brazil. Applied Geochemistry 24, 760-767.

Kharaka, Y. K. and Hanor, J. S., 2003. 5.16 - Deep Fluids in the Continents: I. Sedimentary Basins. In: Heinrich, D. H. and Karl, K. T. (Eds.), Treatise on Geochemistry. Pergamon, Oxford.

Kihm, J.-H., Kim, J.-M., Wang, S., and Xu, T., 2012. Hydrogeochemical numerical simulation of impacts of mineralogical compositions and convective fluid flow on trapping mechanisms and efficiency of carbon dioxide injected into deep saline sandstone aquifers. Journal of Geophysical Research 117, B06204.

Knauss, K. G., Johnson, J. W., and Steefel, C. I., 2005. Evaluation of the impact of $\mathrm{CO}_{2}$, co-contaminant gas, aqueous fluid and reservoir rock interactions on the geologic sequestration of $\mathrm{CO}_{2}$. Chemical Geology 217, 339-350.

Lagneau, V., Pipart, A., and Catalette, H., 2005. Modélisation couplée chimie-transport du comportement à long terme de la séquestration géologique de $\mathrm{CO}_{2}$ dans des aquifères salins profonds. Oil \& Gas Science and Technology - Rev. IFP 60, 231-247.

Lasaga, A. C., Soler, J. M., Ganor, J., Burch, T. E., and Nagy, K. L., 1994. Chemical weathering rate laws and global geochemical cycles. Geochimica et Cosmochimica Acta 58, 2361-2386.

Linjordet, A. and Grung Olsen, R., 1992. The Jurassic Snøhvit gas fields, Hammerfest Basin, offshore Northern Norway. In: Halbouty, M. T. (Ed.), Giant oil and gas fields of the decade 1978-1988, Proceedings of the Conference held in Stavanger, Norway, September 9-12, 1990. American Association of Petroleum Geologists.

Linke, W. F. and Seidell, A., 1965. Solubilities of inorganic and metalorganic compounds. American Chemical Society, Washington D.C.

Liu, N., Liu, L., Qu, X., Yang, H., Wang, L., and Zhao, S., 2011. Genesis of authigene carbonate minerals in the Upper Cretaceous reservoir, Honggang Anticline, Songliao Basin: A natural analog for mineral trapping of natural $\mathrm{CO}_{2}$ storage. Sedimentary Geology 237, 166-178.

Luquot, L., Andreani, M., Gouze, P., and Camps, P., 2012. $\mathrm{CO}_{2}$ percolation experiment through chlorite/zeolite-rich sandstone (Pretty Hill Formation - Otway Basin-Australia). Chemical Geology 294-295, 75-88.

Marchand, A. M. E., Haszeldine, R. S., Smalley, P. C., Macaulay, C. I., and Fallick, A. E., 2001. Evidence for reduced quartz-cementation rates in oil-filled sandstones. Geology 29, 915-918. 
Marini, L., 2006. Geological sequestration of carbon dioxide. Thermodynamics, kinetics and reaction path modeling. Elsevier.

Marion, G. M., Catling, D. C. and Kargel, J. S., 2003. Modeling aqueous ferrous iron chemistry at low temperatures with application to Mars. Geochimica et Cosmochimica Acta 67, 4251-4266.

Marshall, W. L. and Warakomski, J. M., 1980. Amorphous silica solubilities-II. Effect of aqueous salt solutions at $25^{\circ} \mathrm{C}$. Geochimica et Cosmochimica Acta 44, 915-924.

Marshall, W. L. and Chen, C-T. A., 1982. Amorphous silica solubilities-V. Predictions of solubility behavior in aqueous mixed electrolyte solutions to $300^{\circ} \mathrm{C}$. Geochimica et Cosmochimica Acta 46, 289-291.

Martens, S., Kempka, T., Liebscher, A., Lüth, S., Möller, F., Myrttinen, A., Norden, B., SchmidtHattenberger, C., Zimmer, M. and Kühn, M., 2012. Europe's longest-operating on-shore CO2 storage site at Ketzin, Germany: a progress report after three years of injection. Environmental Earth Sciences 67, 323-334.

Michael, K., Arnot, M., Cook, P., Ennis-King, J., Funnell, R., Kaldi, J., Kirste, D., and Paterson, L., 2009. $\mathrm{CO}_{2}$ storage in saline aquifers I-Current state of scientific knowledge. Energy Procedia 1, 31973204.

Moore, J., Adams, M., Allis, R., Lutz, S., and Rauzi, S., 2005. Mineralogical and geochemical consequences of the long-term presence of $\mathrm{CO}_{2}$ in natural reservoirs: An example from the Springerville-St. Johns Field, Arizona, and New Mexico, U.S.A. Chemical Geology 217, 365-385.

Neufeld, J. A., Hesse, M. A., Riaz, A., Hallworth, M. A., Tchelepi, H. A., and Huppert, H. E., 2010. Convective dissolution of carbon dioxide in saline aquifers. Geophys. Res. Lett. 37, L22404.

Okuyama, Y. and Take, S., 2011. Dawsonite-aragonite association in the Cretaceous Izumi Group, SW Japan: Evidence of $\mathrm{CO}_{2}$-rich fluid invasion in the area of classical study. Journal of Mineralogical and Petrological Sciences 106, 79-84.

Palmer, D. A. and Wesolowski, D. J., 1992. Aluminum speciation and equilibria in aqueous solution: II. The solubility of gibbsite in acidic sodium chloride solutions from 30 to $70^{\circ} \mathrm{C}$. Geochimica et Cosmochimica Acta 56, 1093-1111.

Parkhurst, D. L. and Appelo, C. A. J., 1999. User's guide to PHREEQC (Version 2)--a computer program for speciation, batch-reaction, one-dimensional transport, and inverse geochemical calculations. U.S. Geological Survey. 
Pauwels, H., Gaus, I., le Nindre, Y. M., Pearce, J., and Czernichowski-Lauriol, I., 2007. Chemistry of fluids from a natural analogue for a geological $\mathrm{CO}_{2}$ storage site (Montmiral, France): Lessons for $\mathrm{CO}_{2}$-water-rock interaction assessment and monitoring. Applied Geochemistry 22, 2817-2833.

Pearce, J. M., Holloway, S., Wacker, H., Nelis, M. K., Rochelle, C., and Bateman, K., 1996. Natural occurrences as analogues for the geological disposal of carbon dioxide. Energy Conversion and Management 37, 1123-1128.

Pearce, J. M., Kirby, G. A., Lacinska, A., Bateson, L., Wagner, D., Rochelle, C. A., and Cassidy, M., 2011. Reservoir-scale $\mathrm{CO}_{2}$-fluid rock interactions: Preliminary results from field investigations in the Paradox Basin, Southeast Utah. Energy Procedia 4, 5058-5065.

Pinti, D. L. and Marty, B., 1995. Noble gases in crude oils from the Paris Basin, France: Implications for the origin of fluids and constraints on oil-water-gas interactions. Geochimica et Cosmochimica Acta 59, 3389-3404.

Pitzer, K. S., 1973. Thermodynamics of electrolytes, 1, Theoretical basis and general equations. Journal of Physical Chemistry 77, 268-277.

Pitzer, K. S., 1991. Activity coefficients in electrolyte solutions. Boca Raton, CRC Press.

Pruess, K. and García, J., 2002. Multiphase flow dynamics during $\mathrm{CO}_{2}$ disposal into saline aquifers. Environmental Geology 42, 282-295.

Rochelle, C., Pearce, J. M., Shaw, R., Taylor, H., Turner, G., and Williams, C., 2007. Geochemical interactions between $\mathrm{CO}_{2}$ and host rocks at the Snøhvit field. Results of fluid-rock interaction experiments. British Geological Survey Commissioned Report CR/07/218.

Smith, J. W. and Milton, C., 1966. Dawsonite in the Green River Formation of Colorado. Economic Geology 61, 1029-1042.

Taberner, C., Zhang, G., and Catwright, L., 2009. Injection of Supercritical $\mathrm{CO}_{2}$ into Deep Saline Carbonate Formations, Predictions from Geochemical Modeling. 2009 SPE EUROPEC/EAGE Annual Conference and Exhibition, Amsterdam, The Netherlands.

Truesdell, A.H. and B. F. Jones, 1974. WATEQ a computer program for calculating chemical equilibria of natural waters. Journal of Research of the U.S. Geological Survey 2, 233-248

USDOE, 2007. In-Drift Precipitates/Salts Model. United States Department of Energy (USDOE). 
Vong, C. Q., Jacquemet, N., Audigane, P. and Frykman, P., 2010. Compilation of geochemical data and injected gas compositions for modeling of fluid-rock reactions in the In Salah, Snøhvit, Ketzin and Sleipner CCS sites. CO2REMOVE, Deliverable D2.2.2C+D, restricted access.

Watson, M. N., Zwingmann, N., and Lemon, N. M., 2004. The Ladbroke Grove-Katnook carbon dioxide natural laboratory: $\mathrm{A}$ recent $\mathrm{CO}_{2}$ accumulation in a lithic sandstone reservoir. Energy 29, $1457-1466$.

White, A. F. and Brantley, S. L., 2003. The effect of time on the weathering of silicate minerals: why do weathering rates differ in the laboratory and field? Chemical Geology 202, 479-506.

White, A. F. and Brantley, S. L., 2003. The effect of time on the weathering of silicate minerals: why do weathering rates differ in the laboratory and field? Chemical Geology 202, 479-506.

Wiese, B., Böhner, J., Enachescu, C., Würdemann, H., and Zimmermann, G., 2010. Hydraulic characterisation of the Stuttgart formation at the pilot test site for $\mathrm{CO}_{2}$ storage, Ketzin, Germany. International Journal of Greenhouse Gas Control 4, 960-971.

Wildenborg, T., Bentham, M., Chadwick, A., David, P., Deflandre, J.-P., Dillen, M., Groenenberg, H., Kirk, K., Le Gallo, Y., 2009. Largescale $\mathrm{CO}_{2}$ injection demos for the development of monitoring and verification technology and guidelines (CO2ReMoVe), GHGT 9, Energy Procedia 1, 23672374.

Wilkinson, M., Haszeldine, R. S., Fallick, A. E., Odling, N., Stoker, S. J., and Gatliff, R. W., 2009. $\mathrm{CO}_{2}-$ Mineral Reaction in a Natural Analogue for $\mathrm{CO}_{2}$ Storage-Implications for Modeling. Journal of Sedimentary Research 79, 486-494.

Wolf, M., Breitkopf, O., and Puk, R., 1989. Solubility of calcite in different electrolytes at temperatures between $10^{\circ}$ and $60^{\circ} \mathrm{C}$ and at $\mathrm{CO}_{2}$ partial pressures of about $1 \mathrm{kPa}$. Chemical Geology 76, 291-301.

Worden, R. H., 2006. Dawsonite cement in the Triassic Lam Formation, Shabwa Basin, Yemen: A natural analogue for a potential mineral product of subsurface $\mathrm{CO}_{2}$ storage for greenhouse gas reduction. Marine and Petroleum Geology 23, 61-77.

Worden, R. H., Coleman, M. L., and Matray, J. M., 1999. Basin scale evolution of formation waters: a diagenetic and formation water study of the Triassic Chaunoy Formation, Paris Basin. Geochimica et Cosmochimica Acta 63, 2513-2528.

Würdemann, H., Möller, F., Kühn, M., Heidug, W., Christensen, N. P., Borm, G., and Schilling, F. R., 2010. CO2SINK - From site characterisation and risk assessment to monitoring and verification: 
One year of operational experience with the field laboratory for $\mathrm{CO}_{2}$ storage at Ketzin, Germany. International Journal of Greenhouse Gas Control 4, 938-951.

$\mathrm{Xu}, \mathrm{T}$., 2008. TOUGHREACT testing in high ionic strength brine sandstone systems. Lawrence Berkeley National Laboratory, Berkeley, California, USA.

Xu, T., Apps, J. A., and Pruess, K., 2003. Reactive geochemical transport simulation to study mineral trapping for $\mathrm{CO}_{2}$ disposal in deep arenaceous formations. J. Geophys. Res. 108, 2071.

Xu, T., Kharaka, Y. K., Doughty, C., Freifeld, B. M., and Daley, T. M., 2010. Reactive transport modeling to study changes in water chemistry induced by $\mathrm{CO}_{2}$ injection at the Frio-I Brine Pilot. Chemical Geology 271, 153-164.

Zalba, P. E., Conconi, M. S., Morosi, M., Manassero, M., and Comerio, M., 2011. Dawsonite in tuffs and litharenites of the Cerro Castaño member, Cerro Barcino formation, Chubut group (Cenomanian), Los Altares, Patagonia, Argentina. The Canadian Mineralogist 49, 503-520.

Zerai, B., Saylor, B. Z., and Matisoff, G., 2006. Computer simulation of $\mathrm{CO}_{2}$ trapped through mineral precipitation in the Rose Run Sandstone, Ohio. Applied Geochemistry 21, 223-240.

Zhang, G., Spycher, N., Xu, T., Sonnenthal, E., and Steefel, C., 2006. Reactive Geochemical Transport Modeling of Concentrated Aqueous Solutions: Supplement to TOUGHREACT User's Guide for the Pitzer Ion-Interaction Model.

Zhang, G., Zheng, Z., and Wan, J., 2005. Modeling reactive geochemical transport of concentrated aqueous solutions. Water Resour. Res. 41, W02018.

Zhang, W., Li, Y., Xu, T., Cheng, H., Zheng, Y., and Xiong, P., 2009. Long-term variations of $\mathrm{CO}_{2}$ trapped in different mechanisms in deep saline formations: A case study of the Songliao Basin, China. International Journal of Greenhouse Gas Control 3, 161-180.

Zhu, C., 2005. In situ feldspar dissolution rates in an aquifer. Geochimica et Cosmochimica Acta 69, 1435-1453. 


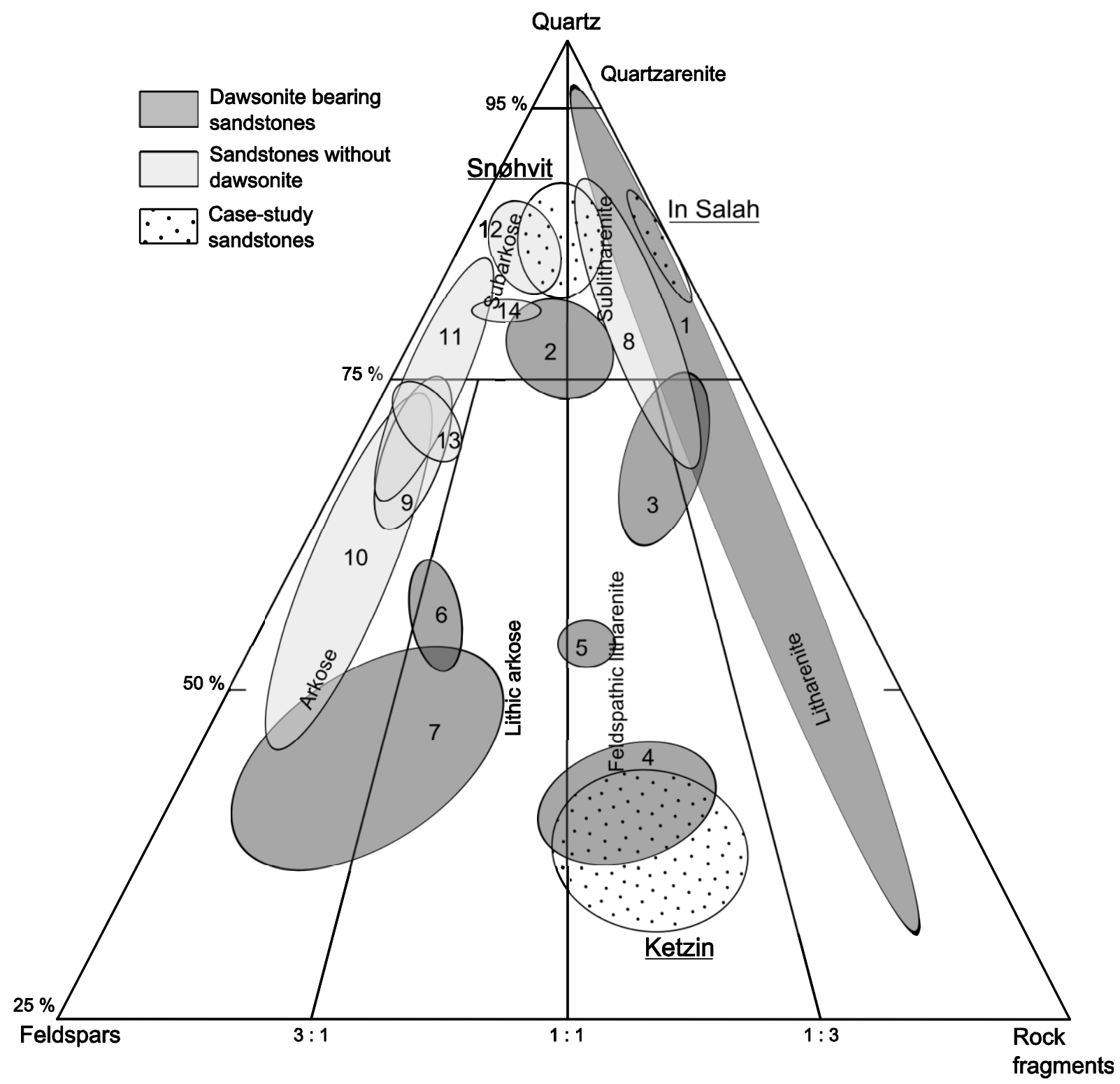

Figure 1 : Folk's diagram of $\mathrm{CO}_{2}$ geologic disposal natural analogue compositions where the presence or absence of dawsonite is shown. Numbers correspond to natural analogues: 1) Bowen-Gunnedah-Sydney Basin; 2) Lam Formation; 3) Fizzy accumulation; 4) Songliao Basin; 5) Cerro Barcino Formation; 6) Springerville - St Johns Field; 7) Hailer Basin; 8) Miller Field; 9) Magnus Field; 10) Bravo Dome; 11) Vert le Grand; 12) Ladbroke Grove Field; 13) Montmiral reservoir; 14) Paradox Basin. Ketzin, In Salah and Snøhvit case-study sandstone compositions are also reported. 

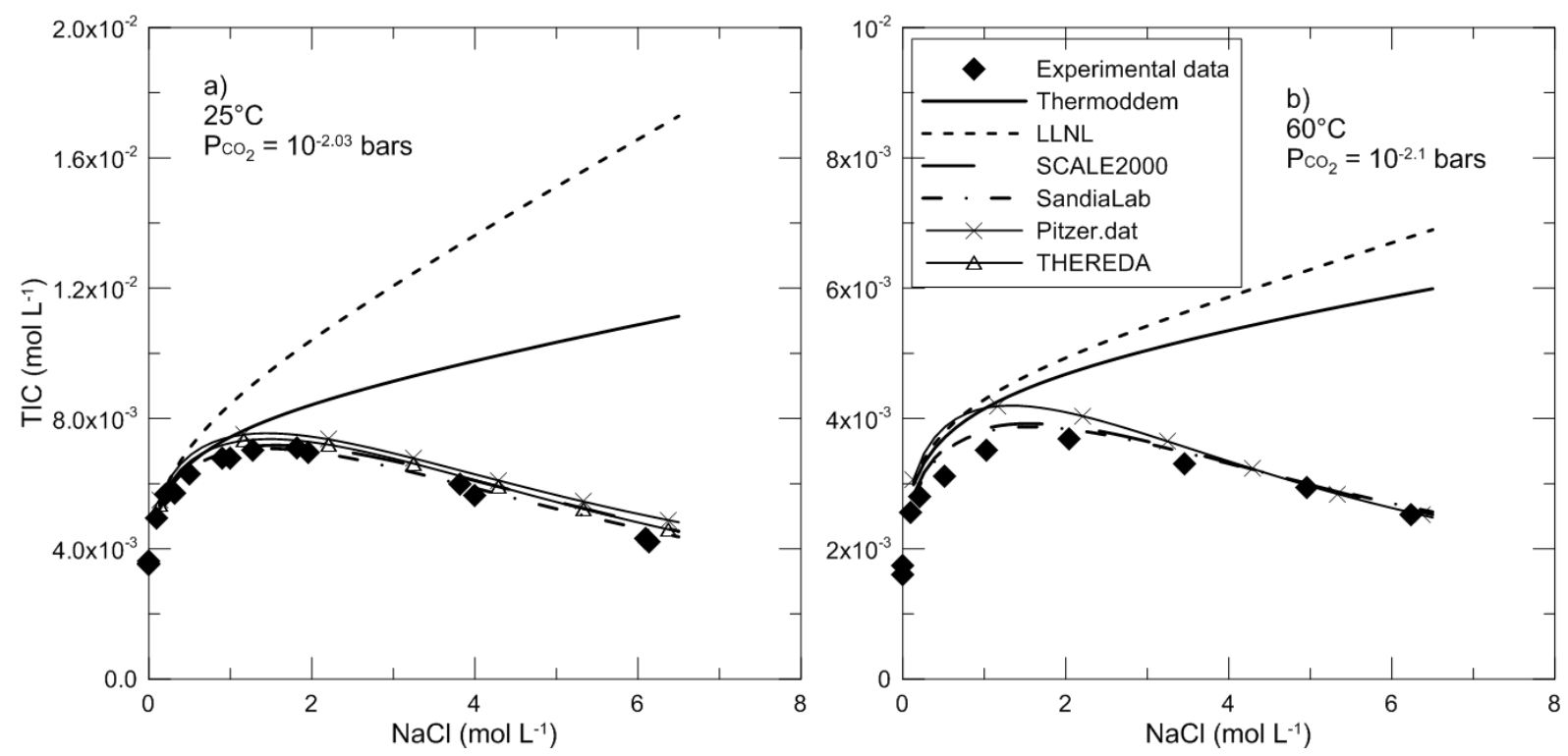

Figure 2: Measured and calculated calcite solubilities in $\mathrm{NaCl}$ solutions at a) $25^{\circ} \mathrm{C}$ and b) $60^{\circ} \mathrm{C}$. Experimental data from Wolf et al. (1989).

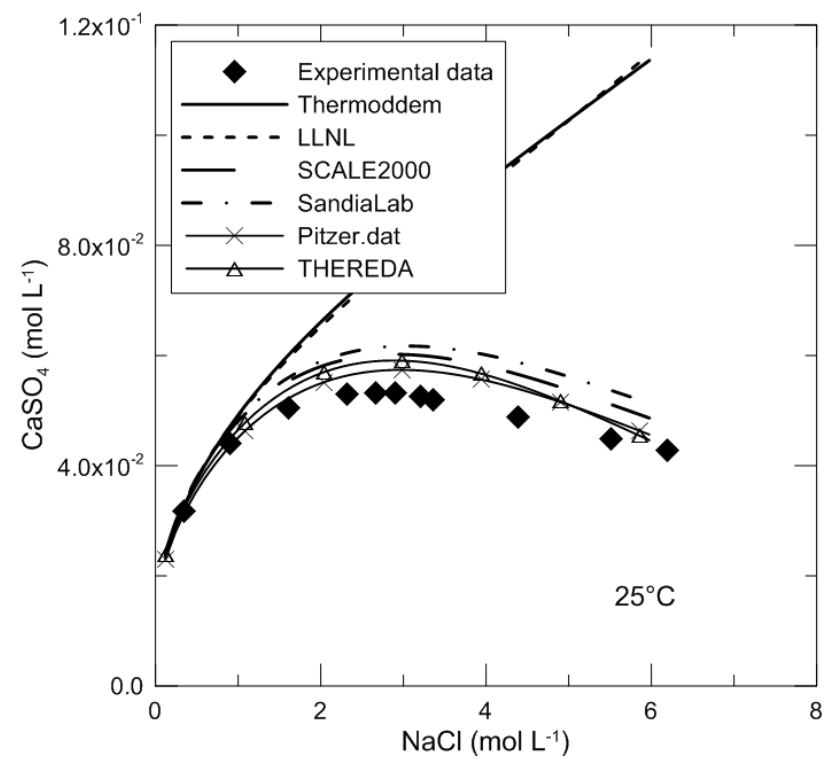

Figure 3: Measured and calculated gypsum solubilities in $\mathrm{NaCl}$ solutions at $25^{\circ} \mathrm{C}$. Experimental data from Linke and Seidell (1965). 

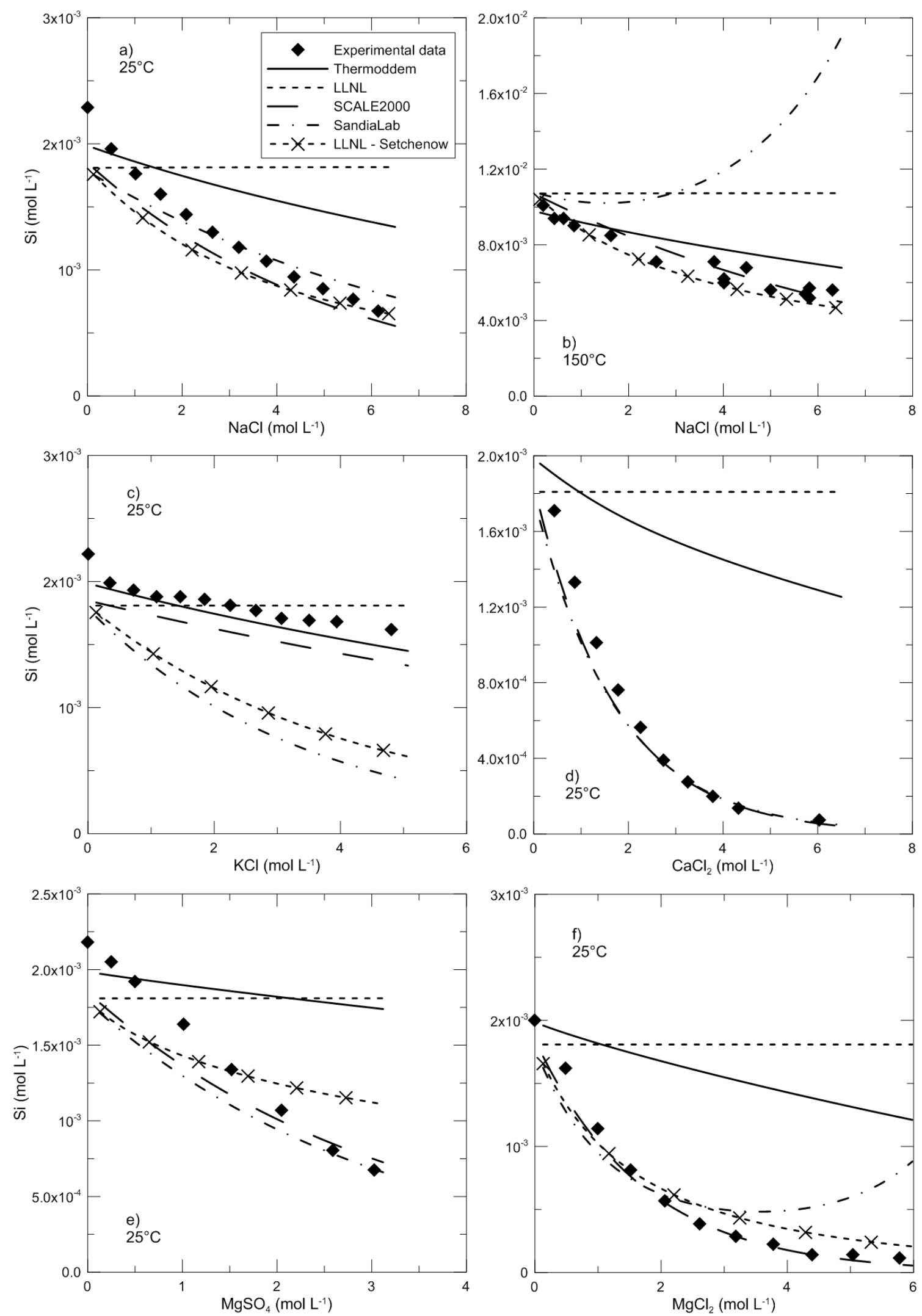

Figure 4: Measured and calculated amorphous silica solubilities in a) $\mathrm{NaCl}$ solutions at $\left.25^{\circ} \mathrm{C}, \mathrm{b}\right) \mathrm{NaCl}$ solutions at $\left.150{ }^{\circ} \mathrm{C}, \mathrm{c}\right) \mathrm{KCl}$ solutions at $25^{\circ} \mathrm{C}$, d) $\mathrm{CaCl}_{2}$ solutions at $25^{\circ} \mathrm{C}$, e) $\mathrm{MgSO}_{4}$ solutions at $25^{\circ} \mathrm{C}$ and f) $\mathrm{CaCl}_{2}$ solutions and $25^{\circ} \mathrm{C}$. Experimental data in $\mathrm{NaCl}$ solutions from Chen and Marshall (1982) and further experimental data from Marshall and Warakomski (1980). 


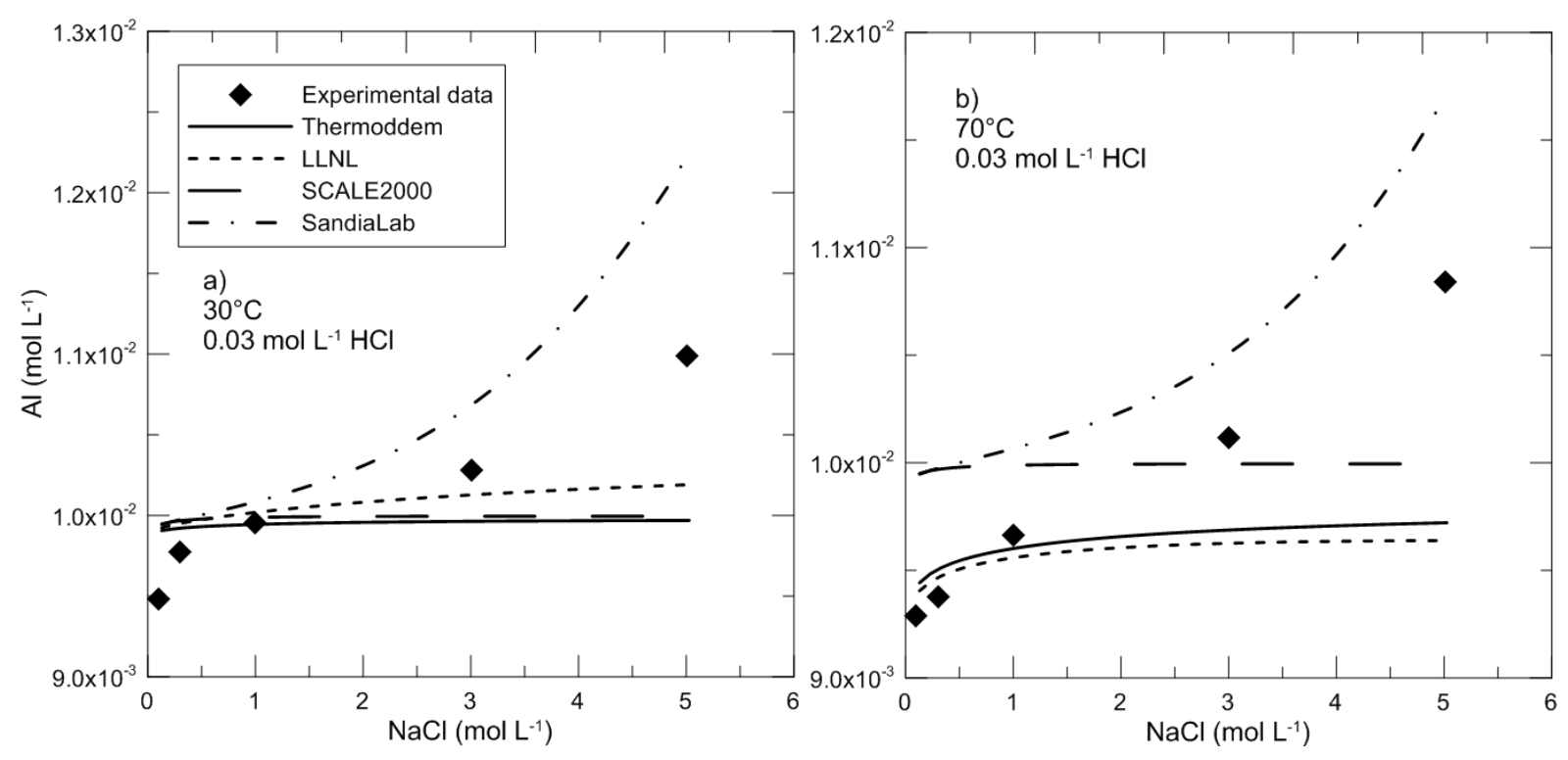

Figure 5: Measured and calculated gibbsite solubilities in $\mathrm{NaCl}$ solutions at a) $30^{\circ} \mathrm{C}$ and b) $70^{\circ} \mathrm{C}$. Experimental data from Palmer and Wesolowski (1992).

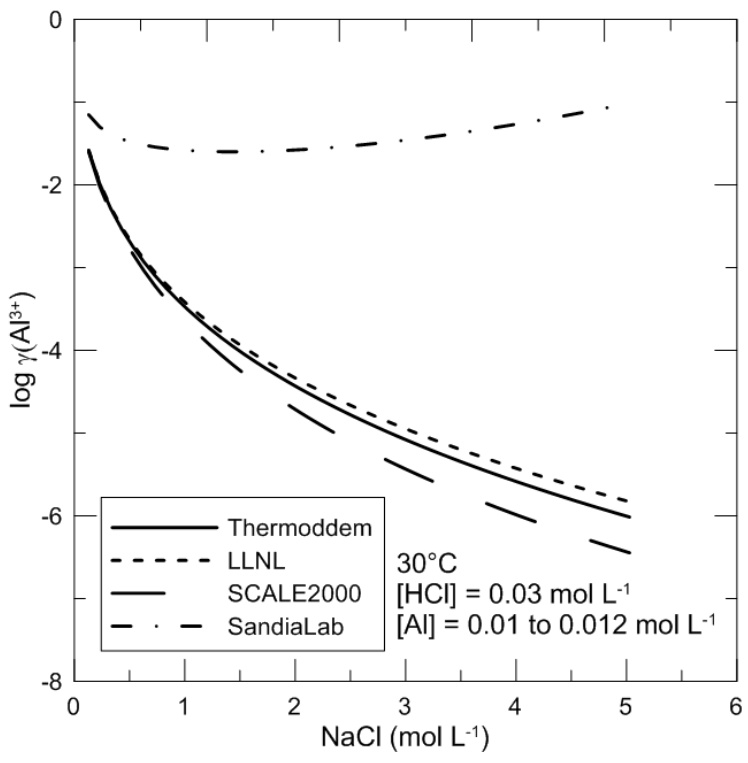

Figure 6: $\mathrm{Al}^{3+}$ activity coefficient evolution as a function of the ionic strength for different databases during gibbsite solubility calculations shown in Figure 5-a. 
STEP 1

Initial conditions
STEP 2

Perturbation by $\mathrm{CO}_{2}$

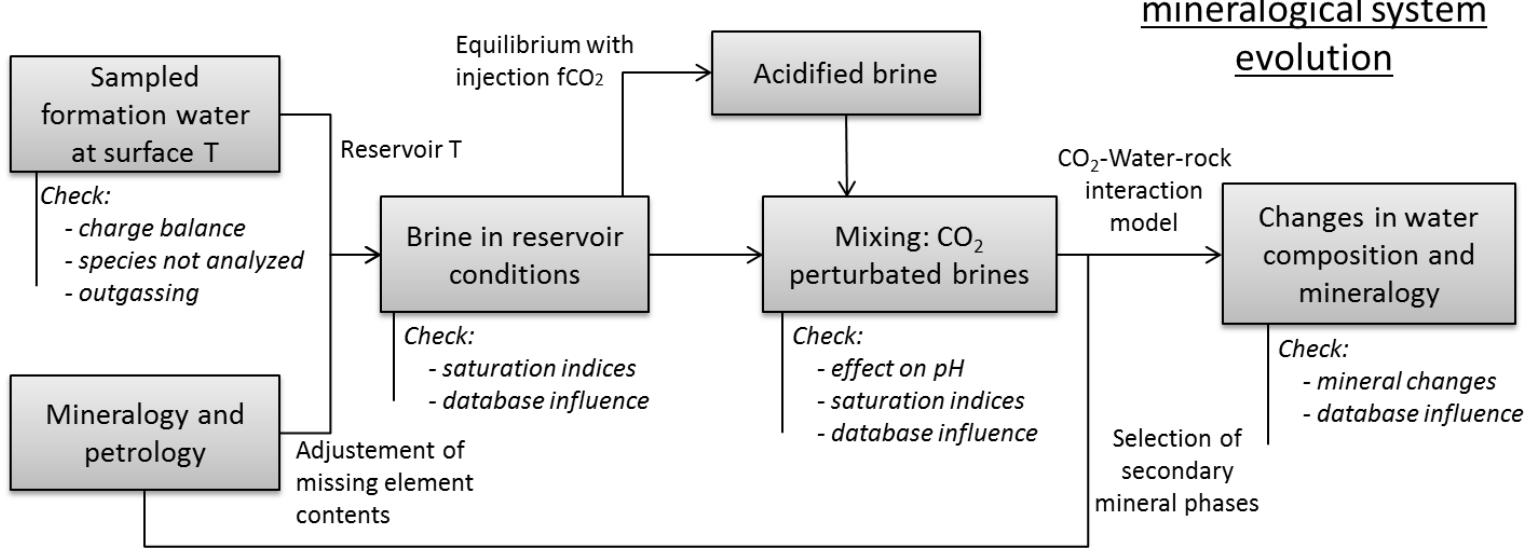

Figure 7: Workflow of the modeling approach proposed to study geochemical fluid - rock interactions induced by $\mathrm{CO}_{2}$ injection in deep saline aquifers. 

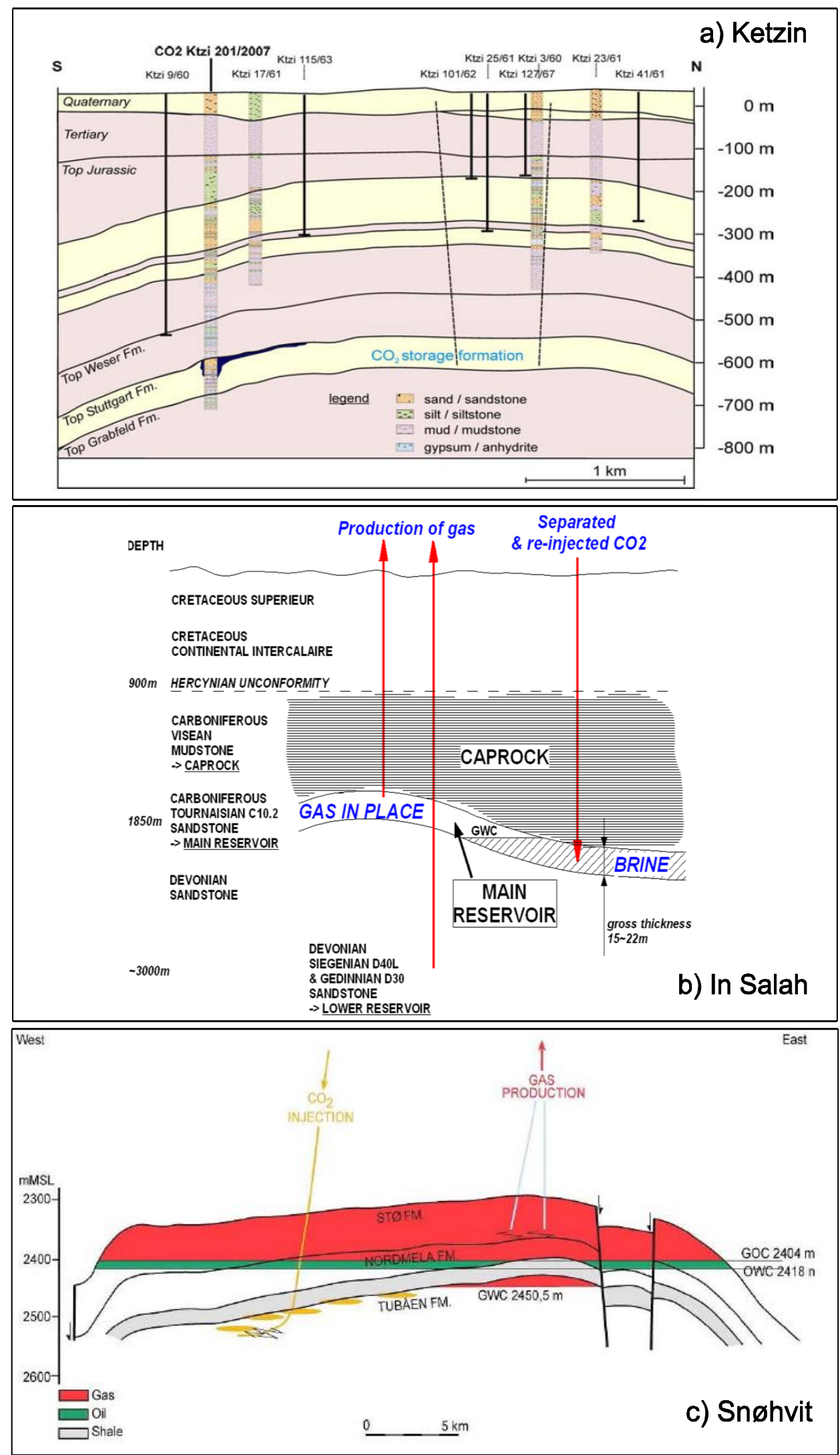

Figure 8: Schematic cross-section of a) Ketzin (Förster et al., 2008), b) In Salah and c) Snøhvit $\mathrm{CO}_{2}$ injection site case-studies. 


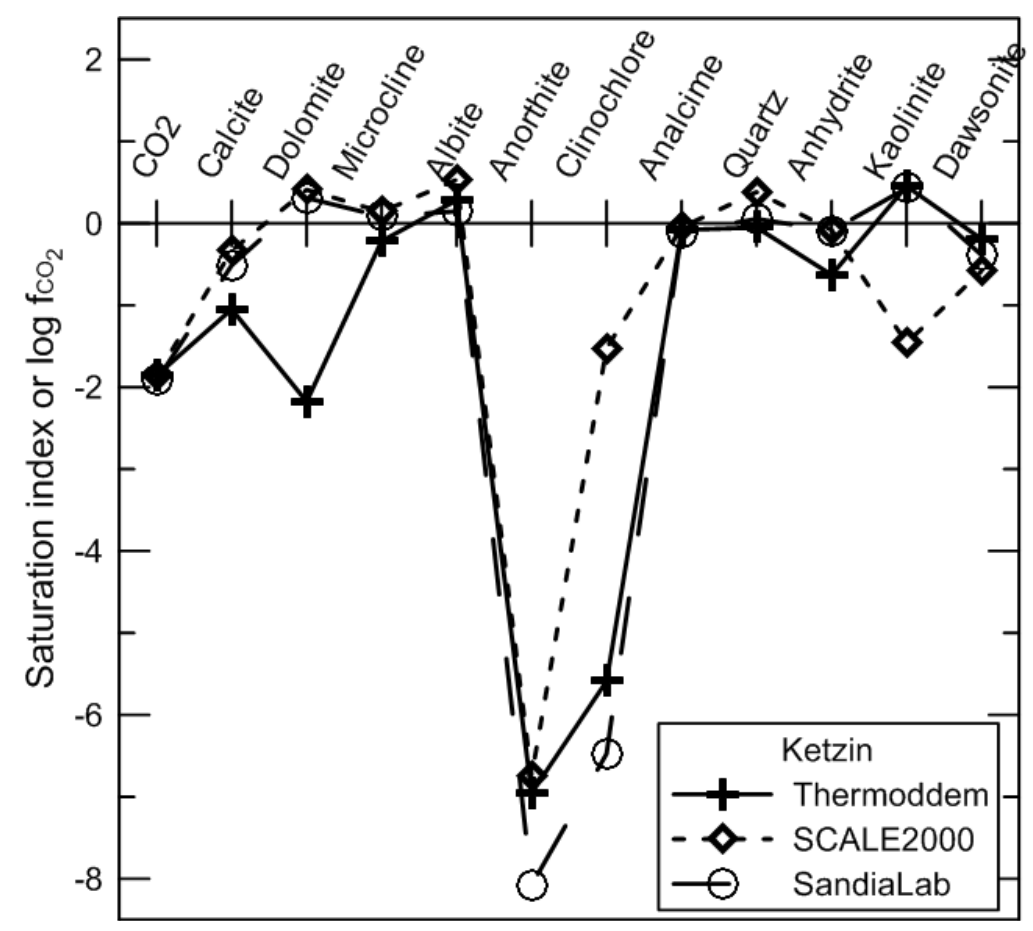

Figure 9: Mineral saturation indices and $\mathrm{CO}_{2}$ fugacities of Ketzin site porewater calculated using SCALE2000, SandiaLab and Thermoddem databases. 

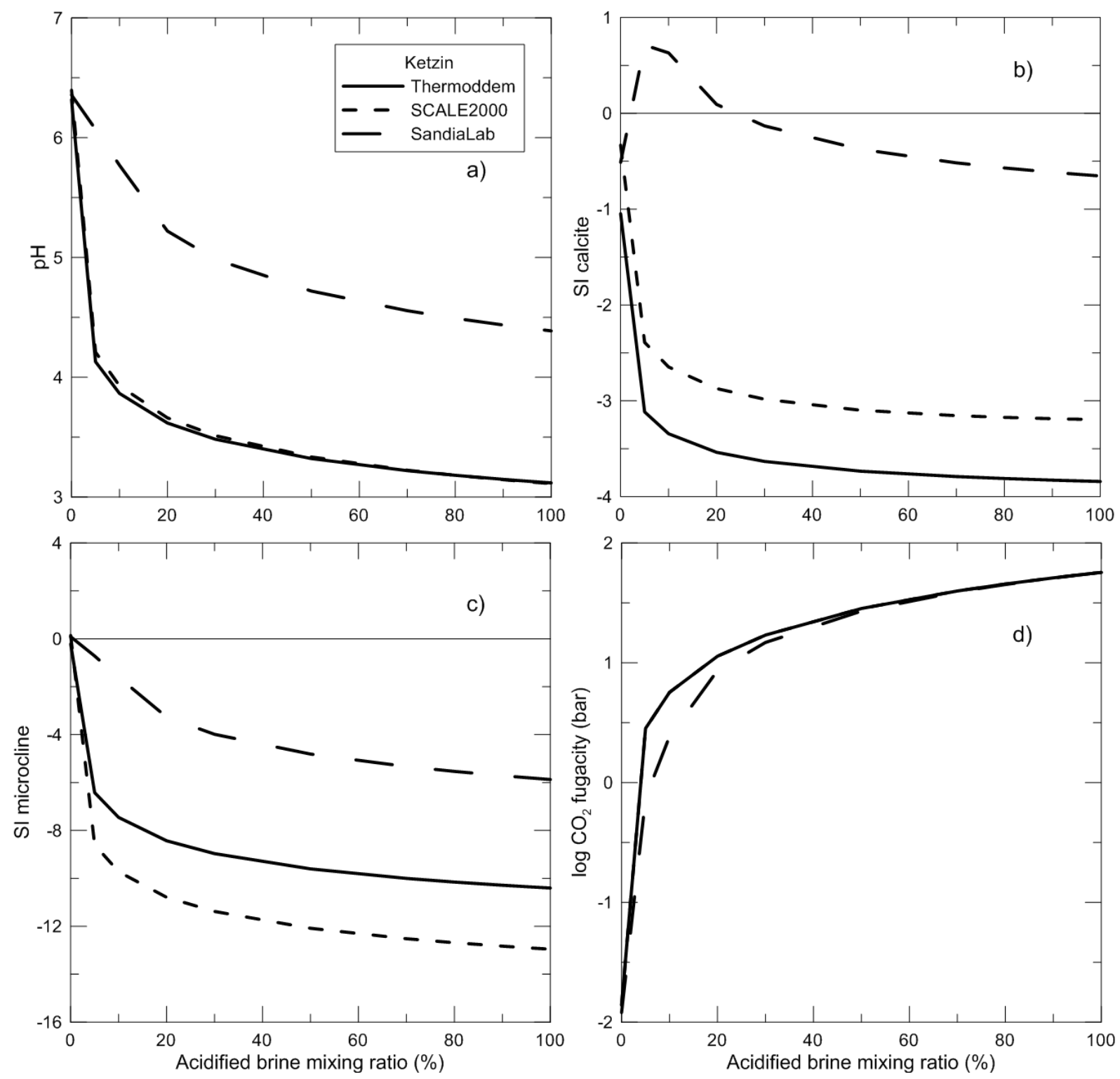

Figure 10: Evolution of a) pH, b) calcite saturation index, c) microcline saturation index and d) $\mathrm{CO}_{2}$ fugacity of Ketzin water as a function of the acidified brine mixing ratio (0\% for Ketzin initial formation water to $100 \%$ for Ketzin water acidified at injection $\mathrm{CO}_{2}$ fugacity) calculated using the SCALE2000, SandiaLab and Thermoddem databases. 

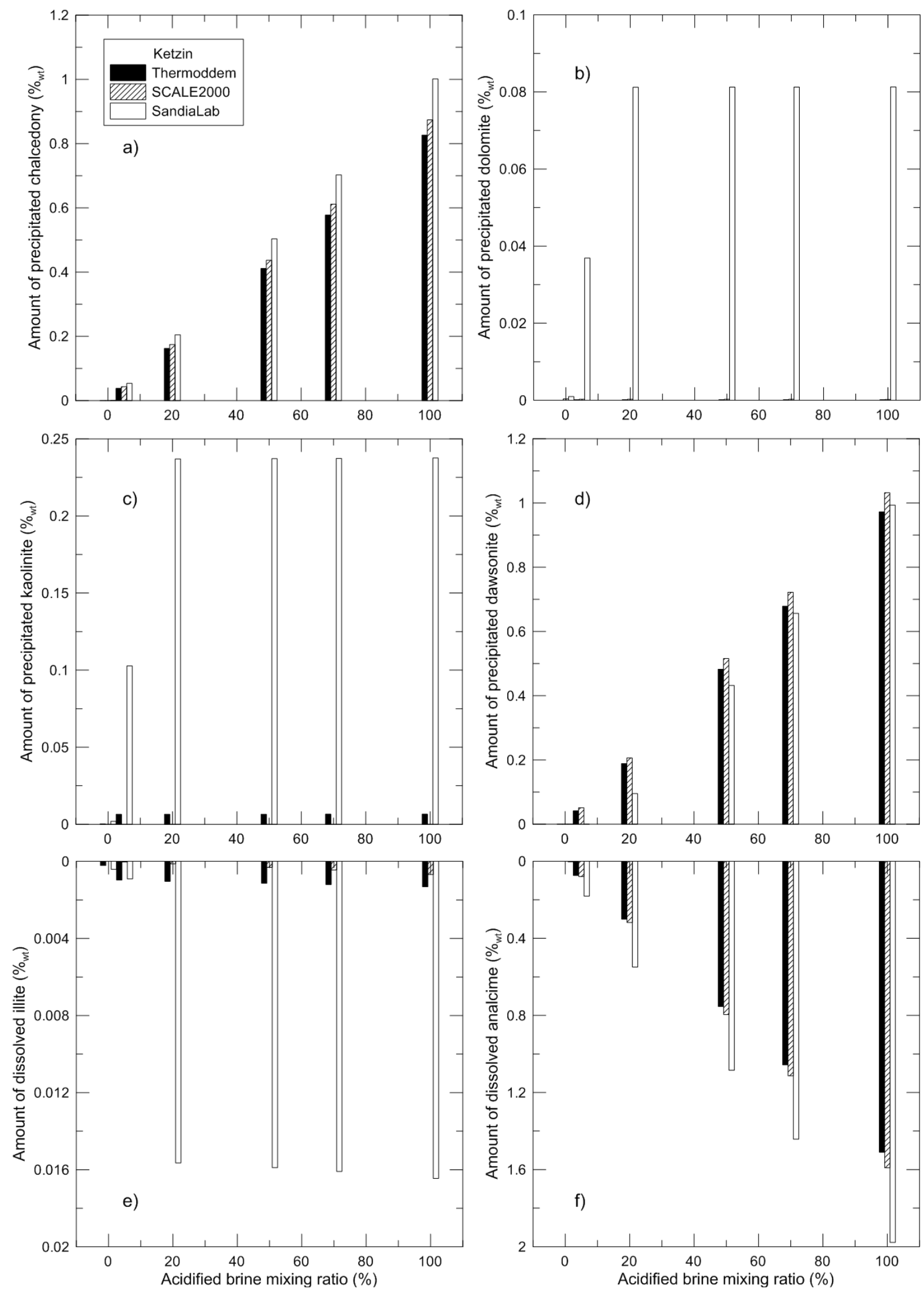

Figure 11: Amounts of a) chalcedony, b) dolomite, c) kaolinite, d) dawsonite, e) illite and f) analcime precipitating or dissolving during $\mathbf{1 0 0 0}$ years for the Ketzin case-study for different acidified brine mixing ratios $(0,5,20,50,70$ and $100 \%)$ calculated using the SCALE2000, SandiaLab and Thermoddem databases. 


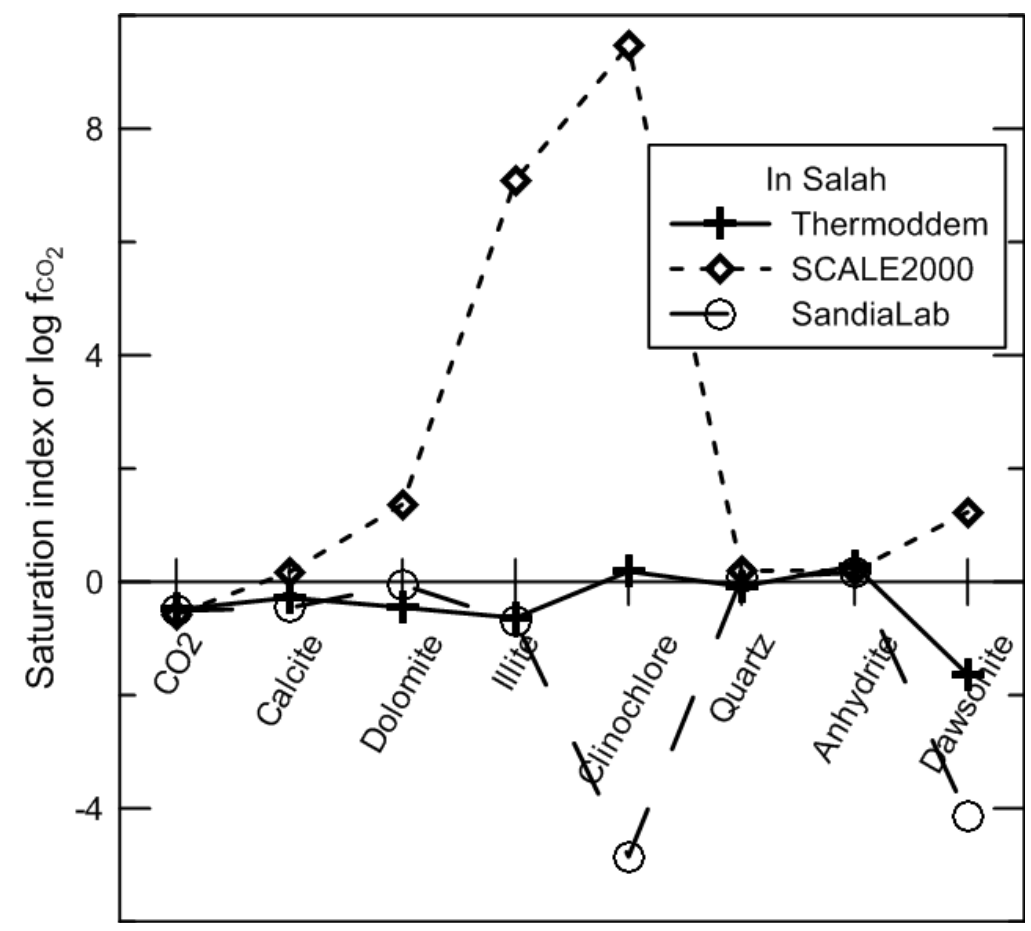

Figure 12: Mineral saturation indices and $\mathrm{CO}_{2}$ fugacity of In Salah site porewater calculated using the SCALE2000, SandiaLab and Thermoddem databases. 

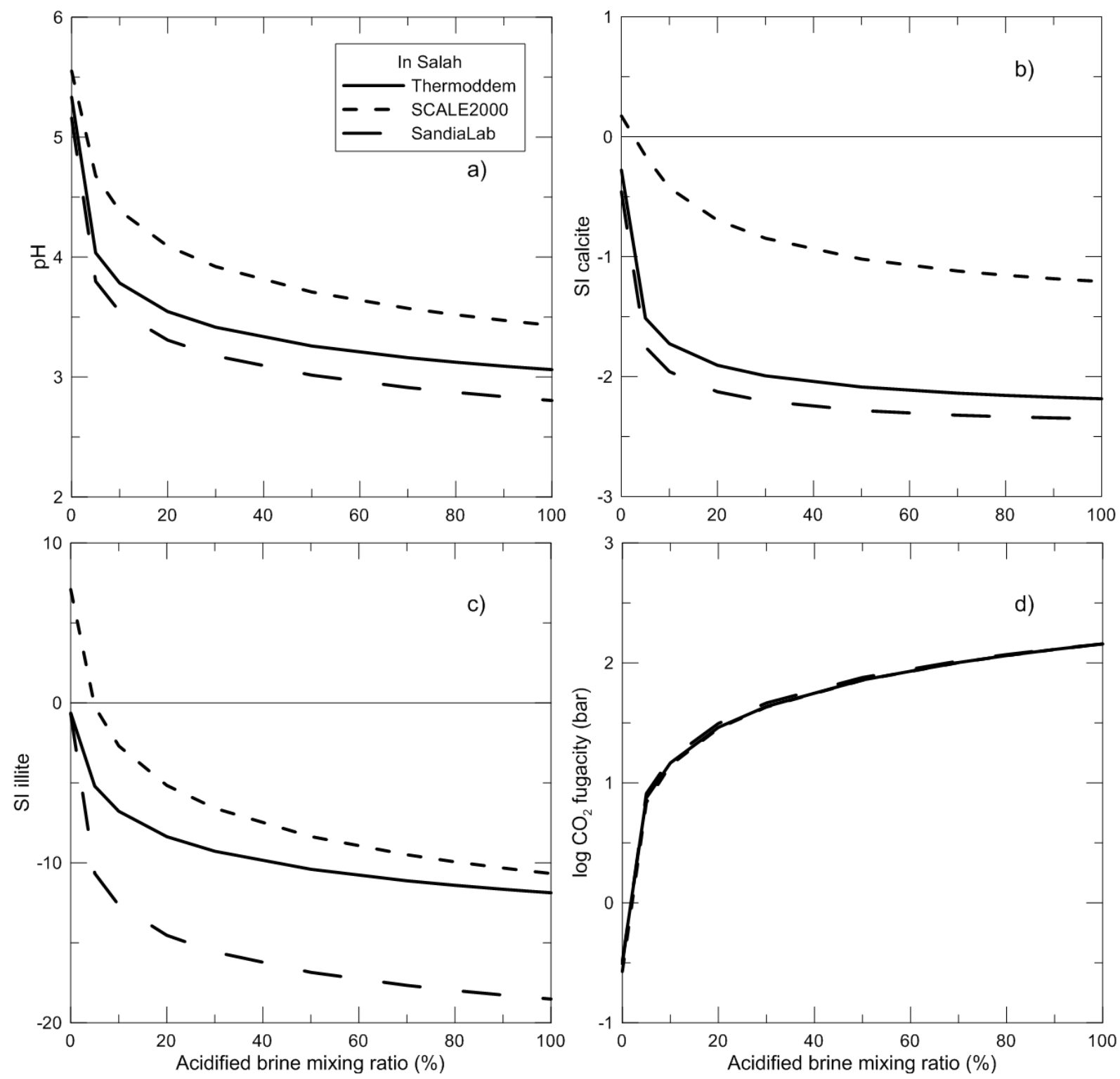

Figure 13: Evolution of a) $\mathrm{pH}$, b) calcite saturation index, c) illite saturation index and d) $\mathrm{CO}_{2}$ fugacity of In Salah water as a function of the acidified brine mixing ratio (0\% for In Salah initial formation water to $100 \%$ for In Salah water acidified at injection $\mathrm{CO}_{2}$ fugacity) calculated using the SCALE2000, SandiaLab and Thermoddem databases. 

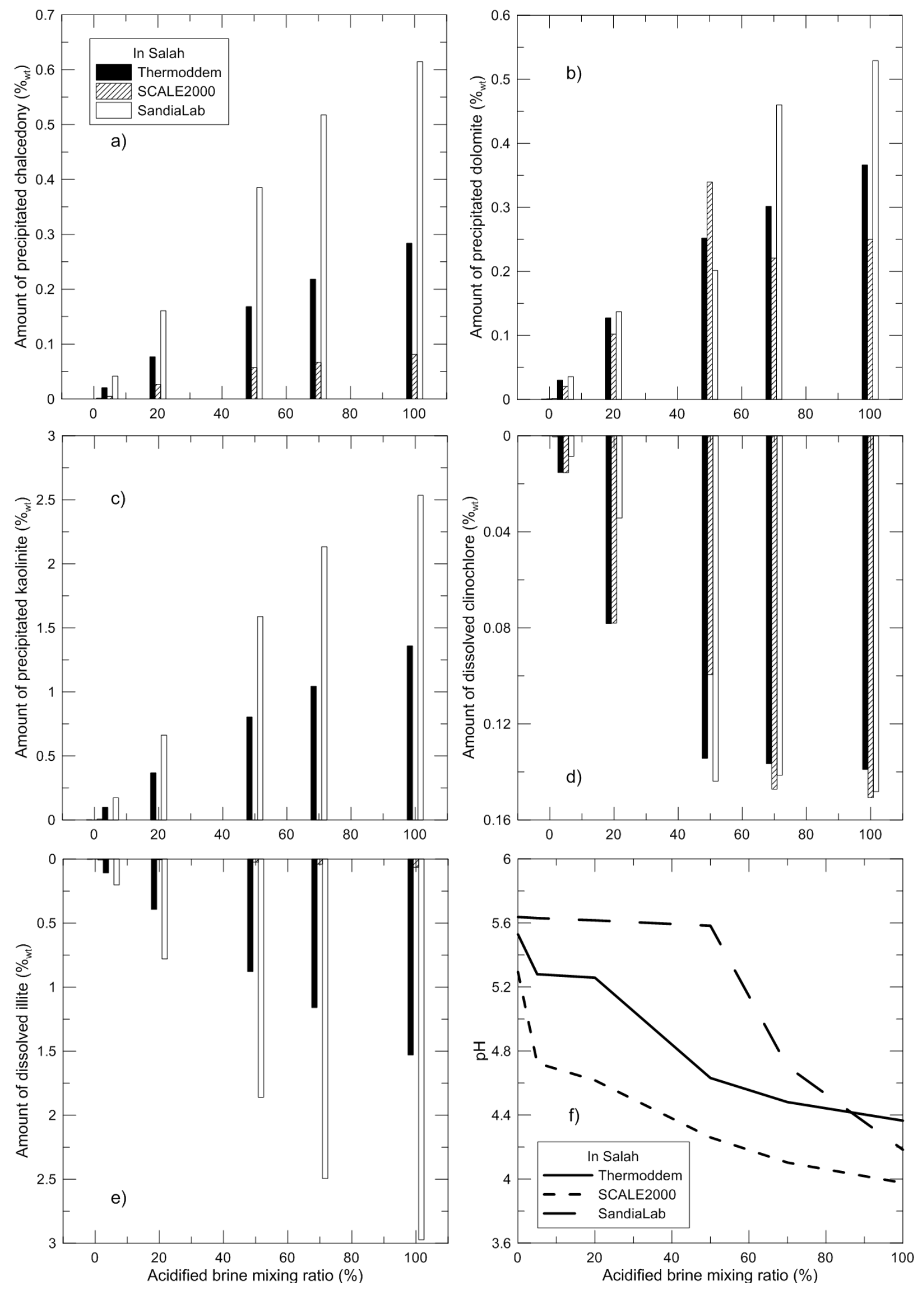

Figure 14: Amounts of a) chalcedony, b) dolomite, c) kaolinite, d) clinochlore and e) illite precipitating or dissolving during 1000 years and f) final pH value for the In Salah case-study for different acidified brine 
mixing ratios $(0,5,20,50,70$ and $100 \%)$ calculated using the SCALE2000, SandiaLab and Thermoddem databases.

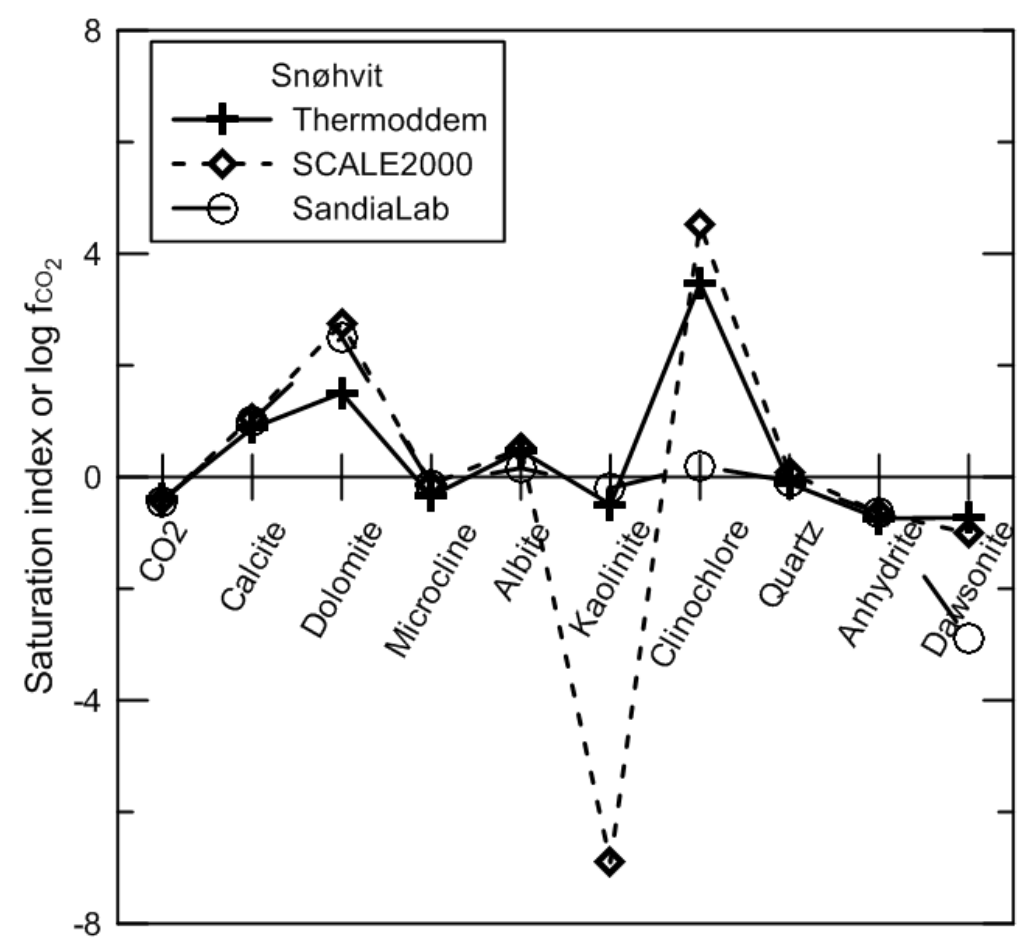

Figure 15: Mineral saturation indices and $\mathrm{CO}_{2}$ fugacities of Snøhvit site porewater calculated using the SCALE2000, SandiaLab and Thermoddem databases. 

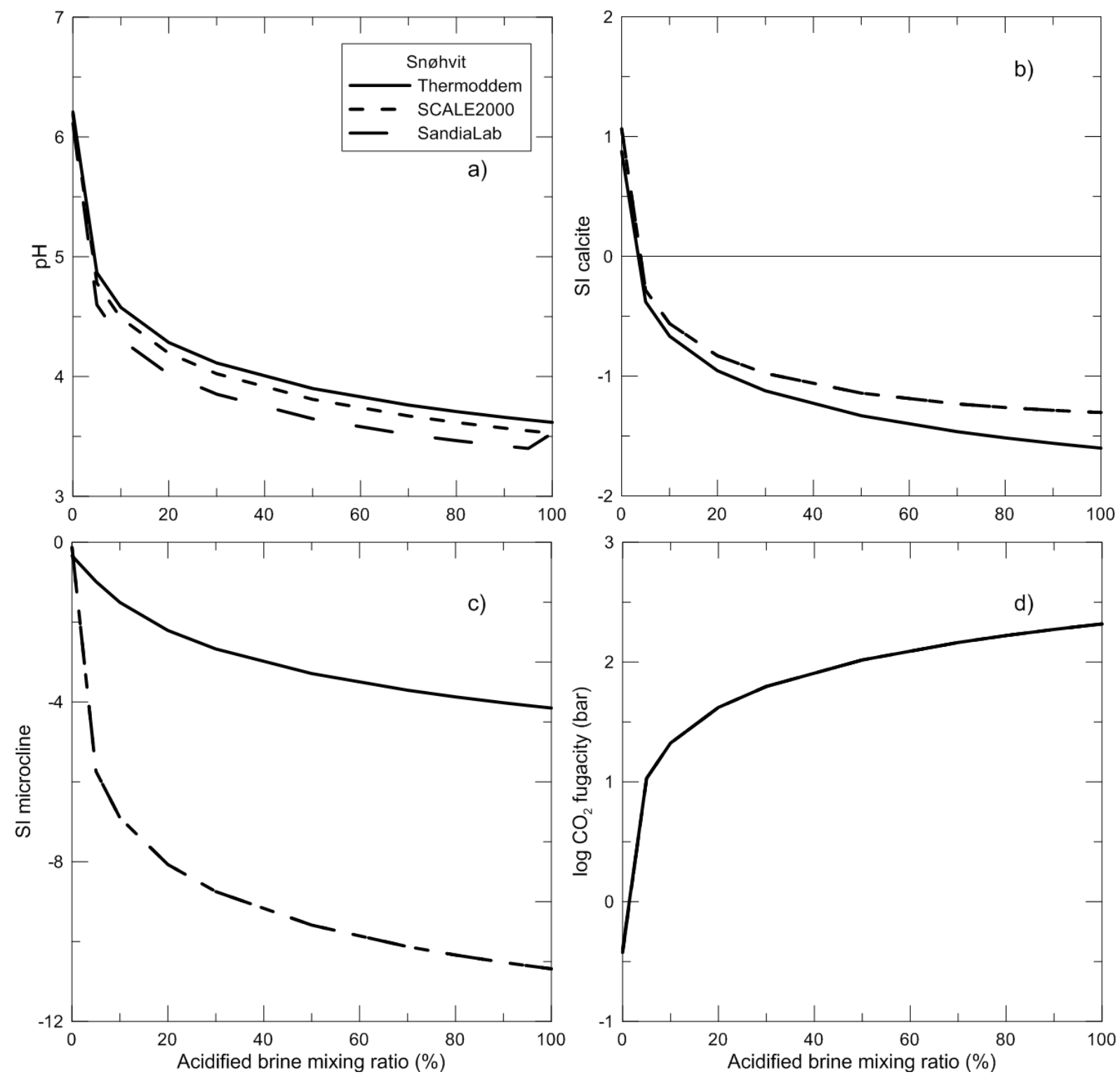

Figure 16: Evolution of a) $\mathrm{pH}$, b) calcite saturation index, c) microcline saturation index and d) $\mathrm{CO}_{2}$ fugacity of Snøhvit water as a function of the acidified brine mixing ratio (0\% for Snøhvit initial formation water to 100 $\%$ for Snøhvit water acidified at injection $\mathrm{CO}_{2}$ fugacity) calculated using the SCALE2000, SandiaLab and Thermoddem databases. 

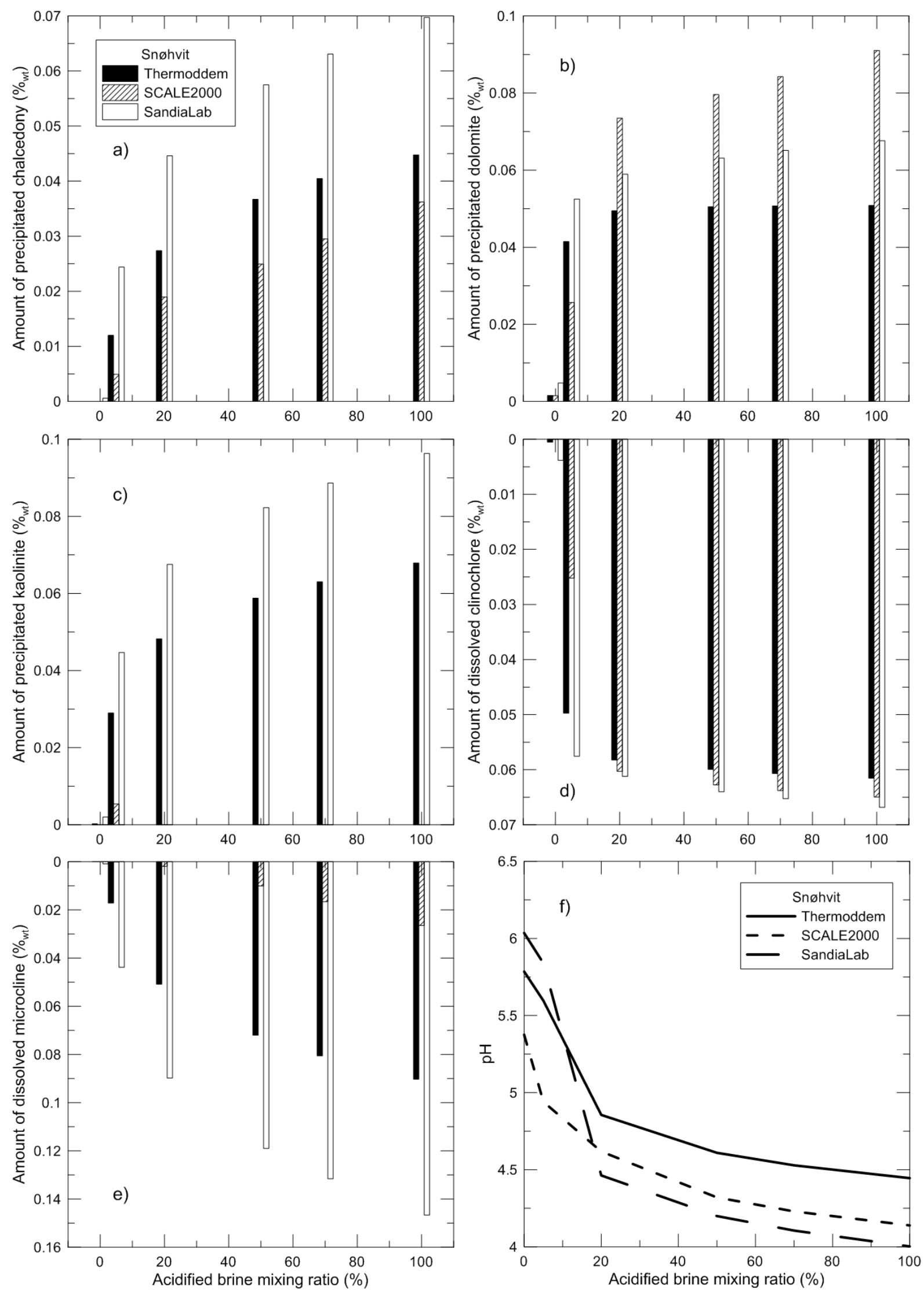

Figure 17: Amounts of a) chalcedony, b) dolomite, c) kaolinite, d) clinochlore and e) microcline precipitating or dissolving during $\mathbf{1 0 0 0}$ years and f) final pH value for the Snøhvit case-study for different acidified brine 
mixing ratios $(0,5,20,50,70$ and $100 \%)$ calculated using the SCALE2000, SandiaLab and Thermoddem databases. 


\begin{tabular}{|c|c|c|c|}
\hline $\begin{array}{l}\text { Name of } \mathrm{CO}_{2} \text { geological } \\
\text { storage analogue }\end{array}$ & Bowen-Gunnedah-Sydney Basin & Cerro Barcino Formation & Miller Field \\
\hline $\begin{array}{l}\text { Geological formation } \\
\text { and location }\end{array}$ & $\begin{array}{l}\text { Permian Aldebaran Sandstone, Freitag Fm, } \\
\text { Cattle Creek Fm, Wilton Fm and Black Jack } \\
\text { Fm. Bowen, Gunnedah and Sydney Basins, } \\
\text { eastern Australia }\end{array}$ & $\begin{array}{l}\text { Cenomanian Cerro Castaño Member, } \\
\text { Cerro Barcino Fm, Chubut Group. Los } \\
\text { Altares, Patagonia, Argentina }\end{array}$ & $\begin{array}{l}\text { Upper Jurassic Brae Fm at Miller oil and } \\
\text { gas Field, South Viking Graben. North Sea, } \\
\text { UK }\end{array}$ \\
\hline References & Baker et al., 1995 & Zalba et al., 2011 & $\begin{array}{l}\text { Baines and Worden, 2004; Marchand et } \\
\text { al., } 2001\end{array}$ \\
\hline $\mathrm{CO}_{2}$ intrusion & $\begin{array}{l}\text { Magmatic } \mathrm{CO}_{2} \text { seepage at continental } \\
\text { scale during Tertiary }\end{array}$ & $\begin{array}{l}\mathrm{CO}_{2} \text { seepage related to a regional } \\
\text { intrusion of alkaline basic dykes during } \\
\text { Eocene }\end{array}$ & $\begin{array}{l}\mathrm{CO}_{2} \text { accumulation mainly from inorganic } \\
\text { crustal source. Accumulation persists at } \\
\text { present-day with } 15.95 \text { to } 64.3 \% \text { of } \mathrm{CO}_{2} \text { in } \\
\text { the gas phase }\end{array}$ \\
\hline $\begin{array}{l}\text { Temperature during } \\
\text { rock- } \mathrm{CO}_{2} \text { interaction }\end{array}$ & Between 25 and $35^{\circ} \mathrm{C}$ & Undetermined & About $120^{\circ} \mathrm{C}$, at present-day \\
\hline $\begin{array}{l}\text { Mineralogical } \\
\text { composition }\end{array}$ & $\begin{array}{l}\text { Quartz rich to rock-fragment rich } \\
\text { sandstones: Quartz, feldspars (K-feldspars } \\
\text { and feldspars from albite to anorthite } \\
\text { series), rock fragments (volcanics, } \\
\text { siliciclastics, metamorphics and granitics), } \\
\text { dawsonite (up to } 13.4 \% \text { with an average } \\
\text { of } 3.5 \% \text { ), quartz, calcite, ankerite, siderite, } \\
\text { kaolinite, illite, illite/smectite, } \\
\text { alumohydroxides and alumohydrocalcite }\end{array}$ & $\begin{array}{l}\text { Zeolitized and silicified tuffs and } \\
\text { feldspathic litharenite sandstones: Quartz } \\
\text { ( } 40 \text { to } 80 \% \text { ), analcime ( } 2 \text { to } 52 \% \text { ), mica ( } 4 \\
\text { to } 7 \% \text { ), sanidine ( } 2 \text { to } 20 \% \text { ), oligoclase ( } 1 \\
\text { to } 13 \% \text { ), calcite (about } 3 \% \text { ), dolomite, } \\
\text { dawsonite (up to } 25 \% \text { and averages about } \\
13 \% \text { ), hematite and halite }\end{array}$ & $\begin{array}{l}\text { Quartz arenite sandstones: Quartz } \\
\text { (detrital and authigenic, } 60 \text { to } 90 \% \text { ), clays } \\
\text { (about } 2 \% \text { ), muscovite ( } 1 \% \text { ), feldspars ( } 2 \\
\text { to } 6 \% \text { ), calcite ( } 2 \text { to } 11 \% \text { ) and pyrite } \\
\text { (about } 2 \% \text { ) }\end{array}$ \\
\hline Brine composition & $\begin{array}{l}\mathrm{NaHCO}_{3} \text {-rich brines, with average } \\
\text { concentrations of } 6090 \text { and } 13360 \mathrm{mg} \mathrm{L}^{-1} \text {, } \\
\text { respectively }\end{array}$ & Na-rich solutions & $\begin{array}{l}\mathrm{Na}, \mathrm{K}, \mathrm{Cl} \text { and } \mathrm{HCO}_{3} \text {-rich brines, with } \\
\text { average contents of } 27365,1310,43960 \\
\text { and } 2495 \mathrm{mg} \mathrm{L}^{-1} \text {, respectively }\end{array}$ \\
\hline $\begin{array}{l}\text { Diagenetic features } \\
\text { linked to the } \mathrm{CO}_{2} \\
\text { intrusion }\end{array}$ & $\begin{array}{l}\text { Dissolution of feldspars and illitic clays. } \\
\text { Precipitation of dawsonite, which fills } \\
\text { pores and fractures and replaces } \\
\text { plagioclases. Dawsonite postdates quartz, }\end{array}$ & $\begin{array}{l}\text { Dissolution of oligoclase and analcime. } \\
\text { Precipitation of dawsonite formed from } \\
\text { analcime dissolution products and } \\
\text { replacing pseudomorphically oligoclase }\end{array}$ & $\begin{array}{l}\text { Extensive dissolution of feldspars (almost } \\
\text { entirely dissolved), limited dissolution of } \\
\text { calcite and creation of secondary porosity } \\
\text { ( } 6 \text { to } 15 \% \text { ). Precipitation of minor }\end{array}$ \\
\hline
\end{tabular}


calcite, ankerite, siderite and kaolinite precipitations, also probably related to $\mathrm{CO}_{2}$ intrusion minerals. Precipitation of quartz, related to the transformation of oligoclase and analcime to dawsonite

\begin{tabular}{|c|c|c|c|}
\hline $\begin{array}{l}\text { Name of } \mathrm{CO}_{2} \text { geological } \\
\text { storage analogue }\end{array}$ & Magnus Field & Bravo Dome & Vert le Grand \\
\hline $\begin{array}{l}\text { Geological formation } \\
\text { and location }\end{array}$ & $\begin{array}{l}\text { Upper Jurassic Magnus Sandstone } \\
\text { member from Kimmeridge Clay Fm, North } \\
\text { Viking Graben. North Sea, UK }\end{array}$ & $\begin{array}{l}\text { Permian Wolfcampian-Leonardian Tubb } \\
\text { Formation of the Bravo Dome reservoir. } \\
\text { Northeastern New Mexico, USA }\end{array}$ & $\begin{array}{l}\text { Upper Triassic Keuper Chaunoy Fm at Vert } \\
\text { le Grand oil field, Paris basin. France }\end{array}$ \\
\hline References & Baines and Worden, 2004 & $\begin{array}{l}\text { Pearce et al., 1996; Baines and Worden, } \\
2004\end{array}$ & $\begin{array}{l}\text { Baines and Worden, 2004; Worden et al., } \\
\text { 1999; Pinti and Marty, 1995 }\end{array}$ \\
\hline $\mathrm{CO}_{2}$ intrusion & $\begin{array}{l}\mathrm{CO}_{2} \text { from thermal maturation of organic } \\
\text { matter. } 2 \% \text { of } \mathrm{CO}_{2} \text { in the actual gas phase }\end{array}$ & $\begin{array}{l}\mathrm{CO}_{2} \text { accumulation linked to recent } \\
\text { volcanic activity }(100,000 \text { to } 8,000 \text { years } \\
\text { ago) }\end{array}$ & $\begin{array}{l}\mathrm{CO}_{2} \text { from organic matter maturation. } 2 \text { to } \\
5 \% \text { of } \mathrm{CO}_{2} \text { in the present-day gas phase. } \\
\mathrm{CO}_{2} \text { addition ceased } 25 \mathrm{Ma} \text { ago }\end{array}$ \\
\hline $\begin{array}{l}\text { Temperature during } \\
\text { rock- } \mathrm{CO}_{2} \text { interaction }\end{array}$ & & & Between 88 and $117^{\circ} \mathrm{C}$, at present-day \\
\hline $\begin{array}{l}\text { Mineralogical } \\
\text { composition }\end{array}$ & $\begin{array}{l}\text { Subarkosic sandstones: Quartz (52 to } 62 \\
\% \text { ), feldspars (K-feldspars and plagioclases, } \\
8 \text { to } 16 \% \text { ) and lithic fragments (illite and } \\
\text { glaucony grains, about } 4 \% \text { ), calcite (about } \\
8 \% \text { ) and pyrite }\end{array}$ & $\begin{array}{l}\text { Arkosic sandstones: } 25 \text { to } 65 \% \text { of K- } \\
\text { feldspars and plagioclases, quartz, clays, } \\
\text { zeolite, carbonates (dolomite, ferroan } \\
\text { dolomite and siderite), hematite }\end{array}$ & $\begin{array}{l}\text { Arkozic sandstones: several tens of } \\
\text { percent of feldspars (K-feldspars, } \\
\text { plagioclases, albite), quartz, carbonate } \\
\text { cements (ferroan dolomite, dolomite and } \\
\text { ferroan calcite) }\end{array}$ \\
\hline Brine composition & $\begin{array}{l}\mathrm{Na}, \mathrm{Cl} \text { and } \mathrm{HCO}_{3} \text {-rich brines, with average } \\
\text { concentrations of } 11090,17375 \text { and } 1040 \\
\mathrm{mg} \mathrm{L}^{-1} \text {, respectively }\end{array}$ & & $\begin{array}{l}\mathrm{Na}, \mathrm{Ca} \text { and } \mathrm{Cl} \text {-rich brines, with average } \\
\text { concentrations of } 22000,3600 \text { and } 40950 \\
\mathrm{mg} \mathrm{L}^{-1} \text {, respectively }\end{array}$ \\
\hline $\begin{array}{l}\text { Diagenetic features } \\
\text { linked to the } \mathrm{CO}_{2} \\
\text { intrusion }\end{array}$ & $\begin{array}{l}\text { Partial dissolution of K-feldspars, } \\
\text { associated with kaolinite and illite } \\
\text { precipitation. Late-precipitation of ferroan } \\
\text { dolomite and ankerite cements }\end{array}$ & $\begin{array}{l}\text { Dissolution of dolomite, sulfate and } \\
\text { aluminosilicates and precipitation of } \\
\text { ferroan dolomite, siderite and small } \\
\text { amounts of kaolinite possibly related to } \\
\text { the } \mathrm{CO}_{2} \text { intrusion. Large amounts of } \\
\text { plagioclases, zeolite and clays remain in } \\
\text { the sandstone }\end{array}$ & $\begin{array}{l}\text { Dissolution of feldspars. Precipitation of } \\
\text { quartz, ferroan dolomite, dolomite and } \\
\text { calcite }\end{array}$ \\
\hline
\end{tabular}




\begin{tabular}{|c|c|c|c|}
\hline $\begin{array}{l}\text { Name of } \mathrm{CO}_{2} \text { geological } \\
\text { storage analogue }\end{array}$ & Lam Formation & Songliao Basin & Hailer Basin \\
\hline $\begin{array}{l}\text { Geological formation } \\
\text { and location }\end{array}$ & $\begin{array}{l}\text { Upper Triassic Tithonian Lam Fm, Shabwa } \\
\text { Basin. Yemen }\end{array}$ & $\begin{array}{l}\text { Upper Cretaceous reservoir in Albian } \\
\text { Qingshankou and Yaojia Fm, Honggang } \\
\text { anticline, Songliao Basin. China }\end{array}$ & $\begin{array}{l}\text { Lower Cretaceous } \mathrm{CO}_{2} \text { gas reservoir in } \\
\text { Namtum Fm, Hailer Basin. China }\end{array}$ \\
\hline References & Worden, 2006 & Liu et al., 2011 & Gao et al., 2009 \\
\hline $\mathrm{CO}_{2}$ intrusion & $\begin{array}{l}\text { Elevated } \mathrm{CO}_{2} \text { fugacity due to an influx of } \\
\text { deep magmatic } \mathrm{CO}_{2}\end{array}$ & $\begin{array}{l}\text { Accumulation of } \mathrm{CO}_{2} \text { from mantle } \\
\text { magmatic source }\end{array}$ & $\begin{array}{l}90 \% \text { of } \mathrm{CO}_{2} \text { in present-day gas phase from } \\
\text { magmatic source. Atmospheric } \mathrm{CO}_{2} \text { also } \\
\text { present during dawsonite precipitation }\end{array}$ \\
\hline $\begin{array}{l}\text { Temperature during } \\
\text { rock- } \mathrm{CO}_{2} \text { interaction }\end{array}$ & 85 to $105^{\circ} \mathrm{C}$ & Between 100 and $120^{\circ} \mathrm{C}$ & Between 85 and $105^{\circ} \mathrm{C}$ \\
\hline $\begin{array}{l}\text { Mineralogical } \\
\text { composition }\end{array}$ & $\begin{array}{l}\text { Subarkosic to sublithic arenite sandstones. } \\
\text { Detrital components: Quartz, feldspars } \\
\text { (mainly K-feldspars, but also plagioclases } \\
\text { and perthite), detrital calcite grains (trace } \\
\text { to } 10 \% \text { ), micas and clays; cement: mainly } \\
\text { carbonates (ferroan calcite, ferroan } \\
\text { dolomite, dawsonite (up to } 8 \% \text { ) and } \\
\text { siderite), quartz and traces of K-feldspars }\end{array}$ & $\begin{array}{l}\text { Lithic arkose to feldspathic litharenite } \\
\text { sandstones: Quartz ( } 23 \text { to } 36 \% \text { ), feldspars } \\
\text { (14 to } 25 \% \text {, mainly K-feldspars but also } \\
\text { plagioclases and perthite), rock fragments } \\
\text { (16 to } 35 \% \text { including clasts from granite, } \\
\text { micas, bioclasts and pyrite). Cement: } \\
\text { dawsonite ( } 2 \text { to } 27 \% \text { ), calcite (up to } 7 \% \text { ), } \\
\text { ankerite (3\%), illite, kaolinite, illite- } \\
\text { smectite, quartz and feldspars ( } 1 \%)\end{array}$ & $\begin{array}{l}\text { Arkose to lithic arkose sandstones: } \\
\text { Feldspars ( } 14 \text { to } 48 \% \text {, mainly K-feldspars } \\
\text { but also plagioclases and perthite), quartz } \\
\text { ( } 24 \text { to } 39 \% \text { ), debris of granite, tuff and } \\
\text { micas ( } 2 \text { to } 26 \% \text { ), dawsonite ( } 2 \text { to } 22 \% \\
\text { with an average of } 10.8 \% \text { ), siliceous } \\
\text { cement (about } 6 \% \text { ), clay minerals (about } \\
2.7 \% \text { ) and ankerite (about } 2.3 \% \text { ) }\end{array}$ \\
\hline Brine composition & $\begin{array}{l}\text { Salinity of } 180000 \text { to } 250000 \mathrm{mg} \mathrm{NaCl} \mathrm{L}^{-1} \\
\text { with an average of } 210000 \mathrm{mg} \mathrm{NaCl} \mathrm{L}^{-1}\end{array}$ & $\begin{array}{l}\text { Salinity ranges between } 17000 \text { and } \\
144000 \mathrm{mg} \mathrm{NaCl} \mathrm{L}^{-1} \text { with an average of } \\
56000 \mathrm{mg} \mathrm{NaCl} \mathrm{L}^{-1}\end{array}$ & $\mathrm{NaHCO}_{3}$-dominated brines \\
\hline $\begin{array}{l}\text { Diagenetic features } \\
\text { linked to the } \mathrm{CO}_{2} \\
\text { intrusion }\end{array}$ & $\begin{array}{l}\text { Dissolution of K-feldspars and albite. } \\
\text { Precipitation of dawsonite, which replaced } \\
\text { K-feldspars and perthite grains and quartz, } \\
\text { followed by precipitations of ferroan } \\
\text { dolomite and siderite }\end{array}$ & $\begin{array}{l}\text { Dissolution of feldspars and primary } \\
\text { calcite. } \\
\text { Precipitation of dawsonite, kaolinite, } \\
\text { quartz, ankerite and late-generation } \\
\text { calcite }\end{array}$ & $\begin{array}{l}\text { Dissolution of feldspars and muscovite. } \\
\text { Precipitation of quartz, kaolinite, } \\
\text { dawsonite and ankerite as last cement }\end{array}$ \\
\hline
\end{tabular}




\begin{tabular}{|c|c|c|c|}
\hline $\begin{array}{l}\text { Name of } \mathrm{CO}_{2} \text { geological } \\
\text { storage analogue }\end{array}$ & Ladbroke Grove Field & Montmiral reservoir & Fizzy accumulation \\
\hline $\begin{array}{l}\text { Geological formation } \\
\text { and location }\end{array}$ & $\begin{array}{l}\text { Early Cretaceous Pretty Hill Fm, Penola } \\
\text { Trough at Ladbroke Grove, Otway Basin. } \\
\text { Australia }\end{array}$ & $\begin{array}{l}\text { Triassic sandstone, Sud-Est Basin. } \\
\text { Montmiral, southeastern France }\end{array}$ & $\begin{array}{l}\text { Early Permian Rotliegend Group, Fizzy } \\
\text { accumulation. Southern North Sea, UK }\end{array}$ \\
\hline References & Watson et al., 2004 & Pauwels et al., 2007 & Wilkinson et al., 2009 \\
\hline $\mathrm{CO}_{2}$ intrusion & $\begin{array}{l}26 \text { to } 57 \% \text { of } \mathrm{CO}_{2} \text { in the gas phase, related } \\
\text { to recent volcanic activity ( }<1 \mathrm{Ma})\end{array}$ & $\begin{array}{l}97.2 \% \text { of } \mathrm{CO}_{2} \text { in the gas phase. } \mathrm{CO}_{2} \\
\text { accumulated since } 35 \mathrm{Ma}\end{array}$ & $\begin{array}{l}\text { About } 50 \% \text { of } \mathrm{CO}_{2} \text { in the gas phase, for at } \\
\text { least } 50 \mathrm{Ma}\end{array}$ \\
\hline $\begin{array}{l}\text { Temperature during } \\
\text { rock- } \mathrm{CO}_{2} \text { interaction }\end{array}$ & & $103^{\circ} \mathrm{C}$ at present-day & 80 to $85^{\circ} \mathrm{C}$ \\
\hline $\begin{array}{l}\text { Mineralogical } \\
\text { composition }\end{array}$ & $\begin{array}{l}\text { Lithic-rich sandstones: Quartz ( } 45 \text { to } 70 \\
\%) \text {, feldspars ( } 5 \text { to } 9 \%) \text {, volcanic rock } \\
\text { fragments ( } 2 \text { to } 7 \% \text { ), kaolinite ( } 6 \text { to } 16 \%) \text {, } \\
\mathrm{Mg} / \text { Fe-carbonates ( } 2 \text { to } 8 \%) \text {, siderite }(1 \text { to } \\
8 \%) \text {, calcite }(<3 \%) \text { and chlorite }(<2 \%)\end{array}$ & $\begin{array}{l}\text { Feldspathic arenite sandstones: Quartz } \\
\text { ( } 62 \text { to } 79 \%), \mathrm{K} \text {-feldspars ( } 20 \text { to } 24 \% \text { ), } \\
\text { mica ( } 1 \text { to } 12 \%) \text {, ankerite ( } 1 \text { to } 2 \% \text { ) and } \\
\text { traces of sphalerite and rutile }\end{array}$ & $\begin{array}{l}\text { Sublitharenite sandstones: Quartz ( } 49 \text { to } \\
62 \%) \text {, fragments of quartz-rich sediments } \\
\text { and muscovite ( } 12 \text { to } 27 \% \text { ), K-feldspars ( } 2 \\
\text { to } 10 \% \text { ), dolomite ( } 1 \text { to } 14 \% \text { ), kaolinite ( } 1 \\
\text { to } 5 \% \text { ), clay minerals (about } 0.5 \% \text { ), } \\
\text { gypsum and anhydrite (about } 1 \% \text { ), } \\
\text { dawsonite ( } 0.1 \text { to } 0.8 \% \text { ) }\end{array}$ \\
\hline Brine composition & $\begin{array}{l}\mathrm{Na}, \mathrm{Ca}, \mathrm{Cl} \text { and } \mathrm{HCO}_{3} \text {-rich brines with a } \\
\text { salinity of } 15000 \mathrm{mg} \mathrm{NaCl} \mathrm{L}^{-1}\end{array}$ & $\begin{array}{l}\mathrm{Na}, \mathrm{Cl} \text { and } \mathrm{SO}_{4} \text {-rich brines with a salinity of } \\
85000 \mathrm{mg} \mathrm{NaCl} \mathrm{L}^{-1}\end{array}$ & \\
\hline $\begin{array}{l}\text { Diagenetic features } \\
\text { linked to the } \mathrm{CO}_{2} \\
\text { intrusion }\end{array}$ & $\begin{array}{l}\text { Massive dissolution of feldspars, chlorite } \\
\text { and calcite. } \\
\text { Precipitation of quartz, kaolinite (replacing } \\
\text { chlorite), ankerite and Fe/Mg-carbonates } \\
\text { (replacing plagioclases). Precipitation of } \\
\text { carbonates mainly in the gas phase zone, } \\
\text { where the } \mathrm{HCO}_{3} \text { content is } 10 \text { times higher } \\
\text { than in the water zone of the reservoir }\end{array}$ & $\begin{array}{l}\text { Dissolution of K-feldspars, ferroan } \\
\text { dolomite and halite. } \\
\text { Precipitation of kaolinite }\end{array}$ & $\begin{array}{l}\text { Dissolution of K-feldspars. } \\
\text { Precipitation of dolomite, little amounts } \\
\text { of dawsonite and probably of quartz }\end{array}$ \\
\hline
\end{tabular}




\begin{tabular}{|c|c|c|}
\hline $\begin{array}{l}\text { Name of } \mathrm{CO}_{2} \text { geological } \\
\text { storage analogue }\end{array}$ & Springerville - St Johns Field & Paradox Basin \\
\hline $\begin{array}{l}\text { Geological formation } \\
\text { and location }\end{array}$ & $\begin{array}{l}\text { Permian Supai Fm, Springerville - St Johns } \\
\text { gas Field. Colorado Plateau, Arizona, USA }\end{array}$ & $\begin{array}{l}\text { Jurassic Entrada sandstones, Paradox } \\
\text { Basin. Colorado Plateau, Utah, USA }\end{array}$ \\
\hline References & Moore et al., 2005 & Pearce et al., 2011 \\
\hline $\mathrm{CO}_{2}$ intrusion & $\begin{array}{l}\text { About } 90 \% \text { of } \mathrm{CO}_{2}(\mathrm{~g}) \cdot \mathrm{CO}_{2} \text { accumulation } \\
\text { related to Pio-Pliocene volcanic activity }\end{array}$ & $\begin{array}{l}\text { Circulation of } \mathrm{CO}_{2} \text {-rich fluids related to } \\
\text { Pio-Pliocene volcanic activity }\end{array}$ \\
\hline \multicolumn{3}{|l|}{$\begin{array}{l}\text { Temperature during } \\
\text { rock- } \mathrm{CO}_{2} \text { interaction }\end{array}$} \\
\hline $\begin{array}{l}\text { Mineralogical } \\
\text { composition }\end{array}$ & $\begin{array}{l}\text { Siltstones: Quartz ( } 26 \text { to } 46 \% \text { ), } \\
\text { plagioclases and K-feldspars ( } 6 \text { to } 13 \% \text {, } \\
\text { each), } 5 \text { to } 18 \% \text { of illite, muscovite and } \\
\text { biotite, kaolinite ( } 2 \text { to } 6 \% \text { ), dolomite ( } 10 \\
\text { to } 15 \% \text { ), calcite ( } 1 \text { to } 2 \% \text { ), dawsonite ( } 5 \text { to } \\
17 \% \text { ), gypsum ( } 1 \text { to } 9 \% \text { ), anhydrite ( } 1 \text { to } 2 \\
\% \text { ) and hematite ( } 4 \text { to } 8 \% \text { ) }\end{array}$ & $\begin{array}{l}\text { Quartz (79 \%), K-feldspars, albite, mica, } \\
\text { pyrite }(0.5 \%) \text { and hematite }(0.5 \%)\end{array}$ \\
\hline Brine composition & $\begin{array}{l}\mathrm{Na}, \mathrm{Mg}, \mathrm{SO}_{4} \text { and } \mathrm{HCO}_{3} \text {-rich brines with a } \\
\text { salinity of } 4210 \mathrm{mg} \mathrm{NaCl} \mathrm{L}^{-1}\end{array}$ & \\
\hline $\begin{array}{l}\text { Diagenetic features } \\
\text { linked to the } \mathrm{CO}_{2} \\
\text { intrusion }\end{array}$ & $\begin{array}{l}\text { Dissolution of K-feldspars, plagioclases } \\
\text { and calcite. } \\
\text { Precipitation of dawsonite and kaolinite }\end{array}$ & $\begin{array}{l}\text { Dissolution of lithic clasts, K-feldspars and } \\
\text { albite. } \\
\text { Precipitation quartz, carbonates and } \\
\text { kaolinite }\end{array}$ \\
\hline
\end{tabular}


Table 2: Aquifer brine compositions prior to $\mathrm{CO}_{2}$ injection at Ketzin (Sample KTZI 202, No 26 from Würdermann et al., 2010), In Salah and Snøhvit.

\begin{tabular}{|c|c|c|c|}
\hline Components & $\begin{array}{l}\text { Ketzin } \\
\mathrm{mg} \mathrm{L}^{-1}\end{array}$ & $\begin{array}{l}\text { In Salah } \\
\mathrm{mg} \mathrm{L}^{-1}\end{array}$ & $\begin{array}{l}\text { Sn } \varnothing \text { hvit } \\
\mathrm{mg} \mathrm{L}^{-1}\end{array}$ \\
\hline $\mathrm{Na}$ & 90400 & 35500 & 56418 \\
\hline $\mathrm{Ca}$ & 2090 & 22400 & 4628 \\
\hline $\mathrm{Mg}$ & 842 & 5276 & 477 \\
\hline $\mathrm{Sr}$ & 48.9 & 506.0 & 207 \\
\hline $\mathrm{Fe}$ & 5.56 & 262 & 14 \\
\hline K & 282 & 225 & 496 \\
\hline $\mathrm{Ba}$ & 0.082 & 10.0 & 4 \\
\hline $\mathrm{Cl}$ & 139000 & 110250 & 96418 \\
\hline $\mathrm{SO}_{4}$ & 3744 & 656 & 210 \\
\hline $\mathrm{HCO}_{3}$ & 58.7 & 178 & 482 \\
\hline I & --- & 6.6 & --- \\
\hline $\mathrm{Br}$ & 44.9 & --- & --- \\
\hline $\mathrm{Si}$ & 8.8 & 38 & 36 \\
\hline $\mathrm{NH}_{4}$ & 18.9 & --- & --- \\
\hline $\mathrm{Mn}$ & 1.4 & 34 & --- \\
\hline $\mathrm{Li}$ & 1.8 & 13 & --- \\
\hline$B$ & 36.2 & 8 & --- \\
\hline $\mathrm{Zn}$ & --- & 1.5 & --- \\
\hline $\mathrm{Ni}$ & --- & --- & 1 \\
\hline $\mathrm{Al}$ & --- & $<3$ & --- \\
\hline $\mathrm{P}$ & --- & $<3$ & --- \\
\hline TDS $\left(\mathrm{g} \mathrm{L}^{-1}\right)$ & 236.5 & 175.4 & 159.4 \\
\hline $\mathrm{pH}$ & 6.4 (at $27^{\circ} \mathrm{C}$ ) & $5.2\left(\right.$ at $20^{\circ} \mathrm{C}$ ) & 6.2 (at $20^{\circ} \mathrm{C}$ ) \\
\hline Density $\left(\mathrm{g} \mathrm{cm}^{-3}\right)$ & 1.151 (at $27^{\circ} \mathrm{C}$ ) & $1.1279\left(\right.$ at $20^{\circ} \mathrm{C}$ ) & $1.104\left(\right.$ at $20^{\circ} \mathrm{C}$ ) \\
\hline
\end{tabular}

Table 3: Mineral phases allowed to dissolve and precipitate in $\mathrm{CO}_{2}$-brine-sandstone interaction models for Ketzin, In Salah and Snøhvit case-studies.

\begin{tabular}{lll}
\hline Case study & $\begin{array}{l}\text { Minerals considered } \\
\text { kinetics dissolution }\end{array}$ & $\begin{array}{l}\text { Minerals considered for } \\
\text { equilibrium precipitation }\end{array}$ \\
\hline Ketzin & Analcime & Chalcedony \\
& Mg-Illite & Dolomite \\
& Microcline & Kaolinite \\
& Clinochlore & Dawsonite \\
\hline In Salah & Mg-Illite & Chalcedony \\
& Clinochlore & Dolomite \\
& & Kaolinite \\
\hline Snøhvit & Microcline & Chalcedony \\
& Clinochlore & Dolomite \\
& & Kaolinite \\
\hline
\end{tabular}


Table 4: Kinetic parameters used in the calculations: reaction rates at $25^{\circ} \mathrm{C}\left(k_{25}\right)$, activation energies $\left(E_{a}\right)$ exponential terms on $\mathrm{H}^{+}$activity $(n)$ and reactive surface areas (A). Analcime kinetic parameters $\left(k_{25}, E_{a}\right.$ and n) taken as leucite parameters.

\begin{tabular}{|c|c|c|c|c|c|c|}
\hline \multirow[b]{2}{*}{ Mineral } & \multirow[b]{2}{*}{$A\left(m^{2} g^{-1}\right)$} & \multicolumn{2}{|c|}{ Neutral mechanism } & \multicolumn{3}{|c|}{ Acid mechanism } \\
\hline & & $\begin{array}{l}\log k^{25} \\
\left(\mathrm{~mol} \mathrm{~m}^{-2} \mathrm{~s}^{-1}\right)\end{array}$ & $\mathrm{E}_{\mathrm{a}}\left(\mathrm{KJ} \mathrm{mol}{ }^{-1}\right)$ & $\begin{array}{l}\log k^{25} \\
\left(\mathrm{~mol} \mathrm{~m}^{-2} \mathrm{~s}^{-1}\right)\end{array}$ & $\mathrm{E}_{\mathrm{a}}\left(\mathrm{KJ} \mathrm{mol}^{-1}\right)$ & $\mathbf{n}$ \\
\hline Analcime & 35.5 & -9.2 & 75.5 & -6 & 132.2 & 0.7 \\
\hline Mg-Illite & 30 & -12.78 & 35.0 & -10.98 & 23.6 & 0.34 \\
\hline Microcline & 0.12 & -12.41 & 38.0 & -10.06 & 51.7 & 0.5 \\
\hline Clinochlore & 0.0027 & -12.52 & 88.0 & -11.11 & 88.0 & 0.5 \\
\hline
\end{tabular}

